\title{
Loricate choanoflagellates (Acanthoecida) from warm water seas. VI. Pleurasiga Schiller and Parvicorbicula Deflandre
}

\author{
Thomsen, Helge Abildhauge; Kamennaya, Nina; Zubkov, Mikhail V.; Østergaard, Jette Buch
}

Published in:

European Journal of Protistology

Link to article, DOI:

10.1016/j.ejop.2020.125717

Publication date:

2020

Document Version

Peer reviewed version

Link back to DTU Orbit

Citation (APA):

Thomsen, H. A., Kamennaya, N., Zubkov, M. V., \& Østergaard, J. B. (2020). Loricate choanoflagellates (Acanthoecida) from warm water seas. VI. Pleurasiga Schiller and Parvicorbicula Deflandre. European Journal of Protistology, 75, [125717]. https://doi.org/10.1016/j.ejop.2020.125717

\section{General rights}

Copyright and moral rights for the publications made accessible in the public portal are retained by the authors and/or other copyright owners and it is a condition of accessing publications that users recognise and abide by the legal requirements associated with these rights.

- Users may download and print one copy of any publication from the public portal for the purpose of private study or research.

- You may not further distribute the material or use it for any profit-making activity or commercial gain

- You may freely distribute the URL identifying the publication in the public portal 


\section{Journal Pre-proof}

Loricate choanoflagellates (Acanthoecida) from warm water seas. VI. Pleurasiga Schiller and Parvicorbicula Deflandre

Helge Abildhauge Thomsen Nina Kamennaya Mikhail V. Zubkov Jette Buch Østergaard

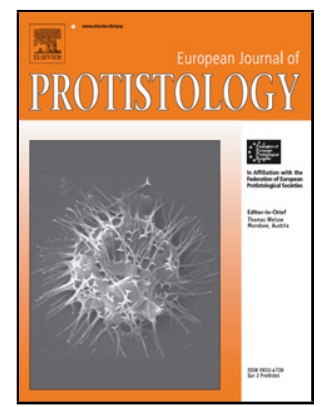

\begin{tabular}{|c|c|}
\hline PII: & S0932-4739(20)30047-X \\
\hline DOI: & https://doi.org/doi:10.1016/j.ejop.2020.125717 \\
\hline Reference: & EJOP 125717 \\
\hline To appear in: & European Journal of Protistology \\
\hline Received Date: & 10 January 2020 \\
\hline Revised Date: & 4 May 2020 \\
\hline ccepted Date: & 15 May 2020 \\
\hline
\end{tabular}

Please cite this article as: Thomsen, H.A., Kamennaya, N., Zubkov, M.V., Ostergaard, J.B.,Loricate choanoflagellates (Acanthoecida) from warm water seas. VI. Pleurasiga Schiller and Parvicorbicula Deflandre, European Journal of Protistology (2020), doi: https://doi.org/10.1016/j.ejop.2020.125717

This is a PDF file of an article that has undergone enhancements after acceptance, such as the addition of a cover page and metadata, and formatting for readability, but it is not yet the definitive version of record. This version will undergo additional copyediting, typesetting and review before it is published in its final form, but we are providing this version to give early visibility of the article. Please note that, during the production process, errors may be discovered which could affect the content, and all legal disclaimers that apply to the journal pertain.

(C) 2020 Published by Elsevier. 
1 Loricate choanoflagellates (Acanthoecida) from warm water seas. VI.

2 Pleurasiga Schiller and Parvicorbicula Deflandre

Helge Abildhauge Thomsen ${ }^{\mathrm{a},}{ }^{*}$, Nina Kamennaya ${ }^{\mathrm{b}, 1}$, Mikhail V. Zubkov $^{\mathrm{b}, 2}$, Jette Buch $\emptyset_{\text {stergaard }}{ }^{\mathrm{c}}$

${ }^{a}$ Technical University of Denmark, National Institute of Aquatic Resources (DTU Aqua), Kemitorvet, Bygning 201, DK 2800 Kgs. Lyngby, Denmark / hat@aqua.dtu.dk

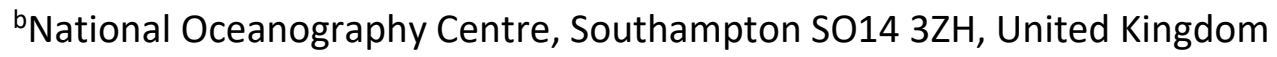

${ }^{c}$ Nørrebrogade 52a 5th, 2200 Copenhagen N, Denmark

*Corresponding author.

E-mail address: hat@aqua.dtu.dk (H.A. Thomsen)

Present address:

${ }^{1}$ The George S. Wise Faculty of Life Sciences, Tel Aviv University, Ramat Aviv 6997801, Israel

${ }^{2}$ The Scottish Association of Marine Sciences, Scottish Marine Institute, Oban, Argyll, PA37 1QA, United Kingdom

\section{Abstract}

The loricate choanoflagellate genera Pleurasiga and Parvicorbicula are taxonomically ambiguous.

Pleurasiga because of the uncertainty that relates to the true identity of the type species, and

Parvicorbicula because too many newly described species over time have been dumped here in

lack of better options. While all species currently allocated to the genus Pleurasiga (with the exception of the type species) are observed in our samples from the global warm water belt, the genus Parvicorbicula is represented by just a few and mostly infrequently recorded taxa. Two new species, viz. Pl. quadrangiella sp. nov. and Pl. minutissima sp. nov., are described here. While the former is closely related to Pl. echinocostata, the latter is reminiscent of PI. minima. Core species of Pleurasiga and Parvicorbicula deviate from the vast majority of loricate choanoflagellates in having both the anterior and the mid-lorica transverse costae located exterior to the longitudinal costae. In Pl. quadrangiella there is no mid-lorica transverse costa but rather a small posterior 
transverse costa located inside the longitudinal costae. In PI. minutissima the mid-lorica transverse costa has extensive costal strip overlaps which reveal patterns of costal strip junctions that deviate from the norm.

Keywords: Acanthoecida; Loricate choanoflagellates; Pleurasiga; Parvicorbicula; Warm water seas

\section{Introduction}

In an ongoing effort (Thomsen and $\varnothing$ stergaard 2019a-e) to provide a first comprehensive overview of warm water loricate choanoflagellate diversity, based on a traditional microscopical approach, we here deal with species of Pleurasiga Schiller, 1925, and Parvicorbicula Deflandre, 1960. Both of these genera are taxonomically problematic, yet in markedly different ways. While the true identity of the Pleurasiga type species (Pl. orculaeformis Schiller, 1925) remains an enigma (Thomsen and Østergaard 2019a, d), the Parvicorbicula type species (Pa. socialis (Meunier, 1910) Deflandre, 1960) is well known (Manton et al. 1976). However, Parvicorbicula has over time become flooded with new species added that have seriously blurred the circumscription of the genus. The morphometric approach taken here will not resolve the taxonomical issues, but hopefully through a critical update on some of the previously described species, and also an addition of species new to science, pave the road for a future more definitive investigation, that can build on the species matrix presented here, while also using whatever sampling technique and molecular tool that might be available.

\section{Material and Methods}

The material that constitutes the background for this and a series of papers on warm water acanthoecid choanoflagellates was collected over a period of 35 years. The geographic origin of 
samples is recorded in Fig. 1. See Thomsen and $\varnothing$ stergaard (2019a) for information on each of the collection sites and sampling campaigns.

In order to substantiate morphological details highlighted below we have added material from Danish waters (Fig. 5a; the Sound, collected Sept. 2014 / Fig. 15a, b; western Kattegat, collected 18 March 1976; 0m, 19 PSU, $0.7^{\circ} \mathrm{C}$ ), New Zealand (Fig. 13a; courtesy of $\varnothing$. Moestrup, Univ. of Copenhagen), South Atlantic Ocean (Fig. 13b; collected 26 Oct. 2017; 42 $7.743^{\prime}$ S, $30^{\circ} 25.023^{\prime}$ W; $20 \mathrm{~m}, 34.5 \mathrm{PSU}, 10.8^{\circ} \mathrm{C} /$ Fig. $14 \mathrm{e}$; collected 26 Oct. $2017 ; 42^{\circ} 1.283^{\prime} \mathrm{S}, 30^{\circ} 4.167^{\prime} \mathrm{W}, 20 \mathrm{~m}, 34.5$ PSU $10.8^{\circ}$ C) and South Pacific Ocean (Fig. 13c; collected 13 Jan. 2016; 36 21.729' S, $132^{\circ} 40.493^{\prime}$ W; $\left.30 \mathrm{~m}, 34.6 \mathrm{PSU}, 16.3^{\circ} \mathrm{C}\right)$.

The general protocol for processing water samples for the light microscope (LM) and transmission electron microscope (TEM) was according to Moestrup and Thomsen (1980) and Thomsen (1982). For details on sample processing, preparational issues and microscopes used see Thomsen and $\varnothing$ stergaard (2019a).

SEM images of cells from the Sound (Fig. 5a) originate from Au-coated coverslip preparations that were prepared in accordance with the routine described by Moestrup and Thomsen (1980) and examined in a FEI Quanta 200 ESEM FEG (property of DTU Cen).

SEM micrographs of specimens from the South Atlantic and South Pacific oceans (Fig. 13b, c, 14e) originate from $\mathrm{Au} / \mathrm{Pd}$-coated polycarbonate filters with flow-sorted cells prepared as described by Kamennaya et al. (2018) and imaged with the high-resolution SEM UltraPlus instrument (Zeiss Gemini) at the Imaging and Analysis Centre of the Natural History Museum in London, UK.

The material examined here is dried, which means that the natural 3-D structures have collapsed to become 2-D structures leading to an artefactual expansion of in particular the lorica 
80 width. While several structures can still be measured with confidence, e.g. lorica height and the

81 length of spines and pedicels, it does imply that certain values such as lorica diameter, typically at

82 the level of the transverse costa(e), cannot be measured directly but only calculated from

83 measurements of the circumference. This approach has been taken in the species descriptions

84 below.

85 Efforts are made to make use of a concise terminology when describing lorica features and we

86 follow the standards that have developed in the course of dealing with these organisms; see e.g.

87 Leadbeater (2015; loc. cit. chapter 4 and glossary p. 278) and Thomsen and Buck (1991). Some

88 essential terms are explained in Fig. 2. Notice that while the term 'mid-lorica transverse costa'

89 refers to the costa that separates longitudinal costal strips two and three (Fig. 2), the term

90 'posterior transverse costa' is used when referring to a transverse costa (viz. Pl. quadrangiella)

91 that separates longitudinal costal strips one and two. Subsamples of species that from a

92 morphological point of view form a fairly well-defined cluster, typically in association with the type

93 species (viz. Parvicorbicula) but also occasionally otherwise (viz. Pleurasiga) are for the sake of

94 simplicity referred to as a 'core' group of species.

95 The unfortunate existence of an electron microscope specific problem causing negatives to

96 appear horizontally flipped, was discussed in Thomsen and $\varnothing$ stergaard (2019d). The evidence in

97 favour of dealing with this problem as a purely technical issue is overwhelming. Scans of the

98 affected negatives have accordingly been flipped horizontally to produce non-reversed images. In

99 the current publication this applies to: Fig. 4a, q; Fig. 5c; Fig. 11a, b, i, q; Fig. 12a-c; Fig. $14 \mathrm{~h}$. 


\section{Pleurasiga Schiller, 1925}

The genus Pleurasiga currently comprises only four mutually closely related species (Fig. 3b, d-

$106 \mathrm{f}$ ) in addition to the enigmatic and only light microscopically studied type species Pl. orculaeformis

107 Schiller, 1925 (Fig. 3a). Efforts to recover material from the Adriatic Sea that convincingly mirrors 108 the Schiller type material (Schiller 1925) have been unsuccessful (Leadbeater 1973). However, as 109 previously discussed (Thomsen and Østergaard 2019a, d) there is a striking similarity between $\mathrm{Pl}$.

110 orculaeformis and species of Polyfibula Manton in Manton and Bremer, 1981, and also to

111 Campanoeca dilatata Throndsen, 1974, a species which was described based on light microscopy

112 only (Throndsen 1974). Species of Pleurasiga are thus clearly in a standby position to be

113 permanently separated from Pl. orculaeformis, and positionally redefined within the loricate 114 choanoflagellate morphospecies matrix.

115 The Pleurasiga lorica is of modest dimensions and constructed from ca. 30 costal strips typically 116 arranged to form two transverse costae of approximately the same size, and seven longitudinal 117 costae. One transverse costa closes the lorica anteriorly, while the second transverse costa (mid118 lorica transverse costa) is shifted downwards corresponding to the length of one longitudinal 119 costal strip. It is a characteristic feature of PI. minima, PI. reynoldsii, and PI. tricaudata, that the 120 transverse costae are nearly of the same size, giving the anterior lorica a quasi-cylindrical 121 appearance. The transverse costae are exterior relative to the longitudinal costae. There are ' $\mathrm{T}$ 122 joints' anteriorly and '4-point' abutting joints at the level of the mid-lorica transverse costa. In 123 species of Pleurasiga the costal strips comprising the longitudinal costae overlap each other from 124 the posterior forwards. This is in general agreement with standard lorica features as outlined by 
Leadbeater (2015). Pleurasiga echinocostata is considered a core member of the genus

(Leadbeater 2015), despite the fact that it has only a single anteriorly located transverse costa which causes the lorica to be conical in outline. At present only two species, viz. Pl. minima and PI. reynoldsii have been sequenced (Nitsche et al. 2017). Not surprisingly they were found to cluster close together. Species of Pleurasiga typically possess a flagellum that reaches far out of the lorica. This indicates that the flagellum does not merely serve the purpose of generating flow fields that aid the filtration of food items in a passively floating organism, but rather that species of Pleurasiga are true pelagic and actively swimming organisms.

\section{Pleurasiga echinocostata Espeland in Espeland and Throndsen, 1986 (Figs. 3f, 4, 5)}

$$
\text { The } P \text {. echinocostata lorica is constructed from approximately } 28 \text { costal strips organized as }
$$
seven longitudinal costae and a single anteriorly positioned transverse costa (Fig. 4a) where the anterior longitudinal costal strips attach to the inside of costal strips from the transverse ring. The exact number of posterior longitudinal costal strips appears to be variable. The lorica illustrated in Fig. 4a has five costal strips while there are only four in Fig. 5q. An examination of the light micrographs (Fig. 4b-p) also hints at that the number of longitudinal costal strips converging at the posterior lorica end is typically less than seven. However, it remains a possibility that the reduced number of posterior longitudinal costal strips is simply caused by loss of strips during preparation or elsewhere. The conical lorica measures 7.5-10.0 $\mu \mathrm{m}$ in length, while the anterior diameter is 5.0-8.3 $\mu \mathrm{m}$ (Espeland and Throndsen 1986). The warm water specimens examined here (Fig. 4a-I) are slightly larger than those comprising the Norwegian type material (i.e. lorica height: $10.5 \pm$ 0.64 $\mu \mathrm{m}$, range: 9.4-11.7 $\mu \mathrm{m}$; transverse costa diameter: $8.5 \pm 0.52 \mu \mathrm{m}$, range: 7.6-9.4 $\mu \mathrm{m} ; \mathrm{n}=28$ ). However, with reference to morphological details there is complete agreement between the type 
material and specimens examined here (e.g. Fig. 4a). More specifically this includes features such as (1) the occurrence of unilateral spines on anterior transverse costal strips, (2) the flattened and slightly forked tip of each anterior longitudinal costa (Fig. 5a, b), which provides structural strength to the positioning of the anterior transverse costal strip (' $T$ '-junctions), and ( 3 ) the overlap between the middle and posterior longitudinal costal strips (Fig. 4a, q), bringing about anchor points for the organic membrane that envelopes the protoplast.

In material examined here (Fig. 4a, 5a, b), the spine is always at the right-hand end of a transverse costal strip when viewing the lorica from the outside. This appears to be a shared feature across material sampled from many parts of the world (Leadbeater 1973, loc. cit. PI. 16e (referred to as Pleurasiga reynoldsii aff.); Espeland and Throndsen 1986, loc. cit. Fig. 32; Booth 1990, loc. cit. Fig. 20; Hoepfner and Haas 1990, loc. cit. Fig. 41; Thomsen et al. 1991, loc. cit. Fig. 35; Hara et al. 1997, loc. cit. Fig. 20; Leadbeater 2015, loc. cit. Fig. 4.64; Thomsen et al. 2016, loc. cit. Fig. 8B). The actual shape of the unilateral costal tip elaboration is that of an asymmetrical fork (Fig. 5a, b) where the subterminal upwardly pointing part of the bifurcation is sharply pointed and more or less perpendicular to the main axis of the costal strip. The other part of the fork, representing the termination of the costal strip, is short and with a rounded tip, and deviates only slightly $\left(25-35^{\circ}\right)$ from the overall curvature of the costal strip. The left-hand end of the transverse costal strip (when viewed from the outside) is obliquely cut off (Fig. 5b) to produce a surface area that snugly fits along the lower terminal fork of the adjacent costal strip.

$$
\text { The region-specific size variability is negligible as appears from Fig. } 6 \text { (circular symbols). }
$$

$$
\text { Pleurasiga echinocostata is easily recognized from LM (Fig. 4b-I). Even the existence of anterior }
$$
spines is evident from some micrographs (e.g. Fig. 4d, e). 
While examining material in particular from West Australia, an aberrant form of $P$.

171 echinocostata (henceforth referred to as form A) was recognized (Fig. 3g; $4 \mathrm{~m}-\mathrm{p}$ ). This form is

172 larger (Fig. 6; square symbols) and has a barrel-shaped, rather than a strictly conical lorica. There

173 are still seven longitudinal costae and a characteristic overlap between the middle and posterior

174 longitudinal costal strips. There is a significant morphological and dimensional similarity between

175 the West Australian material (Fig. 4m-p) and a single specimen observed in samples from the

176 Andaman Sea (Fig. 4q; Fig. 6). Notice that the Andaman Sea specimen (Fig. 4q) has unilateral

177 spines similar to $P$. echinocostata sensu stricto, and that these are also at the right-hand end of

178 the transverse costal strip when viewed from the outside of the lorica.

179 A spine-less variety (henceforth referred to as form B) of P. echinocostata (Fig. 3h; Fig. 5c-e)

180 was observed in samples from the Andaman Sea and the equatorial Pacific Ocean. These

181 specimens all fall within the size ranges (lorica height: 9.5-11.2 $\mu \mathrm{m}$; anterior diameter: 7.8-8.2 $\mu \mathrm{m}$ )

182 that are typical for P. echinocostata sensu stricto (Fig. 6). In addition to the absence of anterior

183 spines, these deviant specimens also lack the characteristic major overlap between the middle and

184 the posterior longitudinal costal strips, that in P. echinocostata sensu stricto produces distinct

185 anchor points to the organic membrane encasing the protoplast. Hara et al. (1997) illustrates (loc.

186 cit. Fig. 21) and comments on the presence in the same Taiwanese water sample of $P$.

187 echinocostata sensu stricto and the spine-less form.

188 Apart from drawing attention to the two morphologically deviant forms (here labelled form $A$ 189 and B respectively) of $P$. echinocostata, it is premature to taxonomically separating them from $P$. 190 echinocostata sensu stricto. Molecular tools and evidence will obviously be needed to support a

191 more confirmative decision with reference to the phylogenetic relationship between these morphotypes. From a purely morphological point of view it appears likely that the form B, which 
differs from $P$. echinocostata sensu stricto with reference to two major characteristics, i.e. the lack of anterior spines and the absence of a major costal strip overlap in the middle part of the lorica, will eventually be singled out as a separate taxon. It is in our opinion more unclear whether the size difference and variability in overall lorica shape, as noticed between $P$. echinocostata sensu stricto and form A, will be sufficient to similarly support the description of a new taxon.

Distribution: Pleurasiga echinocostata sensu stricto has previously been recorded from the Adriatic Sea (Leadbeater 1973; as Pleurasiga reynoldsii aff); Kilsfjorden, Norway (Espeland and Throndsen 1986); the North Pacific Central Gyre (Hoepfner and Haas 1990); the Subarctic North Pacific (Booth 1990); central Californian waters (Thomsen et al. 1991); the equatorial Pacific Ocean (Vørs et al. 1995); Japanese and Taiwanese coastal waters (Hara et al. 1997); Sydney Harbour, Australia (Tong et al. 1998); north-west of South Georgia, Southern Ocean (Leakey et al. 2002); Danish coastal waters (Thomsen et al. 2016); and the Beagle Channel, S. America (Thomsen, unpublished). The findings reported here are summarized in Table 1. Despite extensive collection work reported from both polar regions (e.g. Thomsen and $\emptyset$ stergaard 2017; Thomsen et al. 1997) it is worth pointing out that $P$ l. echinocostata has so far not been recorded at latitudes $>60^{\circ}$ in 208 either hemisphere.

211 Diagnosis: Conical lorica $(9-10 \mu \mathrm{m})$ comprising seven longitudinal costae and two transverse 212 costae, i.e. an anterior ring (seven costal strips; diam. 7.5-8.5 $\mu \mathrm{m}$ ) where 'T-junctions' unite 213 transverse and longitudinal costal strips, and a posterior transverse costa (four costal strips; diam. $2143-4 \mu \mathrm{m}$ ) located at the level of the junctions between the middle and posterior longitudinal costal 215 strips. Anterior transverse costal strips are without unilateral spines. The anterior tip of a 
longitudinal costa is flattened and slightly biforked. The protoplast is located posteriorly and secured by a membrane suspended from the free posterior tips of the middle layer longitudinal costal strips. The flagellum is conspicuous and reaches far outside the lorica.

Holotype: The specimen illustrated in Fig. 7a of the present work is fixed as holotype (ICZN 1999, Article 73.1.4).

Type locality: Surface water sample collected 14 Sept. 1981 from the pier at the Phuket Marine Biological Center (PMBC), Andaman Sea, Thailand (28 ${ }^{\circ}$; 35 PSU).

Etymology: The species-group name is chosen to emphasize the small quadrangular posterior transverse costa; from 'quadrangulus' and '-ella' diminutive.

The main distinguishing feature between Pl. echinocostata and PI. quadrangiella is the presence of a posterior transverse costa in the latter.

The posterior transverse costa is in PI. quadrangiella inside the longitudinal costae. This is particularly evident from Fig. 7c, 8a, b. In Fig. 8b an arrow points to costal strip junctions where the longitudinal element is evidently exterior to the transverse costal strips. The arrowhead (Fig. $8 b)$ points to a transverse costal strip that is sandwiched between longitudinal costae. The possibility that the posterior transverse costa is nothing but randomly re-positioned longitudinal costal strips is highly unlikely, considering the regularity in appearance of the costa (Fig. 7c, d), and the fact that the transverse costal strips forming this costa are morphologically differing in e.g.

234 thickness from the neighbouring longitudinal costal strips. There is no evidence supporting that 235 the internal posterior transverse costa of Pl. quadrangiella should be homologous with the external mid-lorica transverse costa of other species of Pleurasiga. Apart from being internal and external to the longitudinal costae respectively, it can be added that in PI. quadrangiella the transverse costa is at the base of the middle longitudinal costal strip, whereas in other species of 
Pleurasiga the transverse costa is at the level between the upper and middle longitudinal costal strip. A further difference is that while in other species of Pleurasiga the mid-lorica transverse costa has the same number of costal strips as the anterior transverse costa, it applies to Pl. quadrangiella that the posterior transverse costa in this species comprises fewer costal strips. Posterior longitudinal costal strips are markedly reduced in number in Pl. quadrangiella. The lorica illustrated in Fig. 7c has two posterior longitudinal costal strips, while there are three longitudinal costal strips adjoining posteriorly in Fig. 7a. This becomes obvious only when the image is digitally manipulated. In the lorica depicted in Fig. 8a, b there is only a single posterior longitudinal costal strip discernable. In some of the light micrographs (Fig. 7d, g, h) there are no posterior longitudinal costal strips visible. It thus appears that a noticeable reduction in the number of posterior longitudinal costal strips is an innate lorica feature in Pl. quadrangiella in parallel with observations discussed above with reference to Pl. echinocostata.

Recognition of this taxon in the light microscope is easy when examining an empty lorica (Fig. 7d) and possible in most cases also when a protoplast is present (Fig. 7e-i). equatorial Pacific Ocean, and West Australia (Table 1).

Pleurasiga minima Throndsen, 1970 (Figs. 3b, 9, 16)

The PI. minima lorica invariably comprises seven longitudinal costae each consisting of three costal strips. Overlaps between longitudinal costal strip one and two produce distinct anchoring points (Fig. 9a) for the membrane that envelopes the posteriorly positioned protoplast and part of the collar. All seven longitudinal costae adjoin posteriorly in an undamaged lorica (see e.g. Fig. 9a, 
the anterior ring the longitudinal costae attach midway along each of the transverse costal strips, forming 'T-joints' (Fig. 9a). Costal strips from the mid-lorica transverse costa join with longitudinal costal strips in '4-point' abutting joints mostly with short overlaps. Both transverse costae are exterior relative to the longitudinal costae (Fig. 9a).

The lorica height is in our material $15.6 \pm 1.4 \mu \mathrm{m}$ (range: $12.1-19.8 \mu \mathrm{m} ; \mathrm{n}=68$ ). The diameter of the anterior transverse costa is $12.3 \pm 0.8 \mu \mathrm{m}$ (range: 9.8-15.3 $\mu \mathrm{m} ; \mathrm{n}=68$ ), and thus marginally smaller than the mid-lorica transverse costa $(12.7 \pm 1.1 \mu \mathrm{m}$; range: $9.5-16.6 \mu \mathrm{m} ; \mathrm{n}=68)$. There are no obvious regional size differences across the specimens examined (Fig. 10a) except for the occurrence of two unusually large specimens from West Australia. The flagellum protrudes far beyond the lorica (Fig. 9c).

The anterior tips of longitudinal costae have bifurcations (Fig. 9j) that greatly enlarges the contact area between adjoining costal strips. Anterior transverse costal strips often have unilateral spines (Fig. 9j) much similar to those described above from Pl. echinocostata (Fig. 5a, b). The spine is, as was the case also with reference to PI. echinocostata, located at the right-hand end of a costal strip when viewed from the outside of the lorica (Fig. 9a, j). A literature search confirms the generality of this lorica feature (see e.g. Leadbeater 1973, loc. cit. PI. 16b (identified as PI. reynoldsii aff.); Booth 1990, loc. cit. Fig. 21 (identified as PI. cf. minima); Tong 1997a, loc. cit. Fig. $5 a, d)$. It is unclear whether the presence (Fig. 9a) or absence (Fig. 16b) of spines on anterior transverse costal strips in specimens of $P I$. minima is in fact signaling that we are dealing with two separate taxa rather than e.g. temperature induced morphotypes within a single species. Cells with spines are most frequently reported from warm water habitats and virtually absent in PI. minima specimens from high latitude regions (i.e. $>60^{\circ}$ North and South). The recognition of this taxon from light microscopy is straightforward (Fig. 9b-i, k-p). 
286 Distribution: Pleurasiga minima has a genuine cosmopolitan distribution being reported in most 287 loricate choanoflagellate surveys from all biogeographical provinces of the oceans, perhaps with 288 the exception of brackish water sites, such as the innermost parts of the Baltic Sea with salinities 289 below 10 PSU (Thomsen, unpublished results).

291 Pleurasiga minutissima sp. nov. (Figs. 3c, 11-13)

292 Diagnosis: Lorica $10.6 \pm 1.3 \mu \mathrm{m}$ long (range: $8.2-13.0 \mu \mathrm{m} ; \mathrm{n}=67$ ) comprising seven longitudinal 293 and two transverse costae. One costa forms an anterior ring (diam. $8.9 \pm 0.85 \mu \mathrm{m}$; range: 7.3-10.6 $294 \mu \mathrm{m} ; \mathrm{n}=67$ ) where transverse and longitudinal costal strips form 'T-joints'. The mid-lorica 295 transverse costa is located at the junctions between the anterior and middle longitudinal costal 296 strips. This ring is smaller $(6.9 \pm 0.85 \mu \mathrm{m}$; range: $5.2-8.8 \mu \mathrm{m} ; \mathrm{n}=67)$ and with pronounced overlaps 297 between neighbouring strips. Both transverse costae are located exterior to the longitudinal 298 costae. The anterior tip of a longitudinal costa is flattened and slightly biforked. Anterior 299 transverse costal strips are furnished with unilateral spines. The protoplast is located posteriorly 300 and surrounded by a membranous sheet. The flagellum is 2-3 times longer than the lorica.

Holotype: The specimen illustrated in Fig. 11a of the present work is fixed as holotype (ICZN 1999, 303 Article 73.1.4).

304 Type locality: Water sample (15m depth) collected 24 March 1996 at \#31 $\left(9.14 .31^{\circ} \mathrm{N} / 97.21 .12^{\circ}\right.$ 305 W), Andaman Sea, Thailand. The maximum depth at the sampling site is $200 \mathrm{~m}$.

306 Etymology: The species-group name chosen highlights the fact that this species is similar to $\mathrm{Pl}$. minima, yet significantly smaller and with a reduced mid-lorica transverse costa diameter. 
Pleurasiga minutissima is on a superficial view much similar to Pl. minima. The two species

share basic morphometric features such as the presence of seven longitudinal costae (each costa

comprising three costal strips), and two transverse costae (seven costal strips each) forming an

311 anterior ring and a second ring located posteriorly at a distance of one longitudinal costal strip.

312 Transverse costae are in both species exterior to the longitudinal costae. There are in both species

313 'T-joints' anteriorly and variations on the '4-point' abutting overlap theme posteriorly. Flattened

314 and biforked anterior tips on longitudinal costae and unilateral spines on anterior transverse

315 costal strips (right hand end of the strip when viewed from the outside) are further shared

316 features.

317 The most conspicuous differences between the two species refer to (1) lorica height (Fig. 10c)

318 where Pl. minutissima is distinctly smaller (10.6 $\mu \mathrm{m}$ in PI. minutissima vs. $15.6 \mu \mathrm{m}$ in Pl. minima)

319 and (2) transverse costae diameter (Fig. 10d). Those of PI. minutissima are generally smaller (8.9

$320 \mu \mathrm{m}$ vs. $10.3 \mu \mathrm{m}$ ) and also displaying a noticeable mutual size difference, with the mid-lorica

321 transverse costa being significantly smaller $(6.9 \mu \mathrm{m})$. In Pl. minima the two costae are almost of

322 the same size, yet with the mid-lorica transverse costa being marginally larger. The PI. minima

323 lorica chamber is thus almost parallel sided, whereas cone-shaped in PI. minutissima. There are no

324 obvious regional size differences across the specimens examined (Fig. 10b).

325 The Pl. minutissima lorica is sometimes terminated by a posterior spine in the shape of a single

326 costal strip that protrudes fully or partially beyond the point where the longitudinal costae adjoin

327 (Fig. 11n-p, 13b). Whereas Pl. minima is characterized by a posterior amalgamation of all seven

328 longitudinal costae there appears to be in PI. minutissima a certain reduction in the number of

329 posterior longitudinal costal strips (Fig. 11a: 4; Fig. 11b: 5). 
It has been verified from all TEM and SEM micrographs available to us, that the mid-lorica

331 transverse costa is exteriorly located relative to the longitudinal costae. It is similarly evident in

332 undamaged specimens that the flattened and biforked anterior tips of the longitudinal costae

333 attach to the inside of anterior transverse costal strips.

$334 \quad$ Patterns of costal strip junctions have been intensively discussed by Thomsen and $\emptyset$ stergaard

335 (2019d) referring back to observations summarized by Leadbeater (2015) which lead to the

336 formulation of rules of lorica assembly of likely universal validity across major parts of the loricate

337 choanoflagellate species matrix. The lorica assembly model as outlined by Leadbeater (2015) is as

338 follows when focusing in particular on the mid-lorica transverse costa. In this costa, when seen

339 from the outer surface and in a clockwise direction the left-hand end of a costal strip overlaps the

340 right-hand end of the adjacent costal strip. When the junction interacts with a longitudinal costa

341 the triangle is on the right-hand side of the longitudinal costa. When the transverse costae are

342 seen from the inner surface of the lorica the respective triangles are located on the left-hand side

343 of a longitudinal costa. It should be noted that the small triangles referred to are artefactual but

344 are, nevertheless, very consistent in location.

345 However, when scrutinizing images of PI. minutissima as depicted here (in particular Fig. 11a, b,

$34612 a, 13 a-c)$ it is evident, when seen from the outer surface and in a clockwise direction, that the

347 left-hand end of a costal strip underlaps the right-hand end of the adjacent strip, and further that

348 the 'triangles' are located to the left of a longitudinal costa. This deviation in terms of symmetry is

349 unexpected and obviously in need of further confirmation. When carefully examining some of the

350 light micrographs of this species (Fig. 11k, I, n; encircled) it is possible to observe costal strip

351 patterns that support the evidence extracted from e.g. Fig. 11a. The most convincing of these is

352 Fig. 11n where it appears completely obvious that the costal strip junction encircled is located in 
the proximal part of the lorica. The fortunate finding of cells of Pl. minutissima examined in a scanning electron microscope (Fig. 13b, c) convincingly corroborates the fact that there is in $\mathrm{Pl}$. minutissima a reversal of the costal strip pattern with reference to the mid-lorica transverse costa. While the arrowhead (Fig. 13b) points to a junction in the proximal part of the lorica and thus seen from the outside, the arrows (Fig. 13b) similarly point to junctions seen from the inside of the lorica. We have added (Fig. 13c) a South Pacific specimen of PI. minutissima that occurs immediately next to a specimen of Cosmoeca ventricosa form B (Thomsen and Østergaard 2019d). The PI. minutissima specimen displays (Fig. 13c; circles) the exact same variant costal strip pattern as described above, while the $C$. ventricosa specimen (Fig. 13c; squares) adheres to the principles as detailed by Leadbeater (2015). Further evidence can finally be extracted from a New Zealand image (Fig. 13a; courtesy of Dr. Øjvind Moestrup) where costal strip junctions, when observed from the outside, are encircled using a heavy line, while junctions as observed from the inside of the lorica are encircled using a thin line (Fig. 13a). In both cases the patterns are identical to those described above.

It is important to emphasize that the mere identification of the new species from any kind of microscopy is not dependent on that the mid-lorica transverse costal strip pattern is fully resolved. Overall size differences between this species and PI. minima in combination with the much reduced mid-lorica transverse costa diameter in Pl. minutissima are sufficient diagnostic features. It is obvious from any TEM and SEM image of Pl. minutissima that this species shares with $\mathrm{Pl}$. echinocostata, and PI. minima the fact that the spine is placed at the right-hand end of a transverse costal strip when viewed from outside the lorica.

Pleurasiga minutissima is widespread across the global warm water belt (Table 1 ) and additionally observed in samples from the Pettaquamscutt river estuary, Rhode Island, USA 
(Menezes 2005; loc. cit. PI. VIII A identified as PI. minima), New Zealand (Fig. 13a), as well as the South Atlantic (Fig. 13b) and South Pacific Oceans (Fig. 13c).

\section{Pleurasiga reynoldsii Throndsen, 1970 (Fig. 3d, 14a-e)}

This species was infrequently observed in samples from the warm water habitats visited. The specimens collected are marginally smaller than those from the Norwegian type material (Throndsen 1970). The lorica height in our material ranges from 19.5 to $22.0 \mu \mathrm{m}$ (type material: 23 $\mu \mathrm{m})$. It is a characteristic feature of $P$. reynoldsii that the two transverse costae are almost of equal size, but also that the mid-lorica transverse costa is consistently larger than the anterior transverse costa (18.0-19.5 versus 14.5-16.0 $\mu \mathrm{m}$ in our material). Throndsen (1970) simply states that the maximum diameter is $23 \mu \mathrm{m}$. Pleurasiga reynoldsii is distinguished from $P$. minima based on overall size, the differently sized transverse costae in P. reynoldsii, and the amalgamation into pairs of six out of seven longitudinal costae at the posterior lorica end.

Distribution: Pleurasiga reynoldsii has a cosmopolitan distribution being previously observed in samples from Bear Island and Nordåsvatnet, Norway (Throndsen 1970, 1974), Resolute Bay, Canada and Disko Bay, Greenland (Manton et al. 1976), Western Baltic Sea, Denmark (Thomsen 1976; Thomsen et al. 2016), Kaikoura, New Zealand (Moestrup 1979), Prydz Bay and Weddell Sea, Antarctica (Marchant 1985; Thomsen and Larsen 1992), central Californian waters, USA (Thomsen et al. 1991), Igloolik, Canada (Daugbjerg and Vørs 1994), Southampton, UK (Tong 1997b), Darwin, Shark Bay and Sydney Harbour, Australia (Lee et al. 2003; Tong 1997a; Tong et al. 1998), St. Lawrence, Canada (Bérard-Therriault et al. 1999), Bering Sea (Sukhanova 2001), NEW, NE Greenland (Thomsen and Østergaard 2017), and Beagle Channel, Patagonia (Thomsen, 
unpublished results). Here reported from the Gulf of California, the equatorial Pacific Ocean, West Australia and the Sargasso Sea (Table 1).

\section{Pleurasiga tricaudata Booth, 1990 (Fig. 3e, 14e-h)}

Pleurasiga tricaudata is similar to PI. minima in all basic morphometric features. The

distinguishing feature is the compound pedicel that consists of typically three costal strips that flare out like a tripod (Fig. 14e, h). The species is easily recognized from LM (Fig. 14f, g). In PI. tricaudata the anterior tip of middle layer longitudinal costal strips is also bifurcated (Fig. 14e, h). This also occasionally applies to posterior longitudinal costal strips (Fig. 14h; arrow). Both the anterior and the mid-lorica transverse costa are exterior relative to the longitudinal costae (Fig. 14e). There are '4-point' abutting joints at the level of the mid-lorica transverse costae. However, these are slightly more elaborate than just abutting which reveals that the joint pattern is similar to that described above for Pl. minutissima. The left-hand end of a transverse costal strip, when viewed in a clockwise direction, clearly underlaps the neighboring strip (Fig. 14e; arrows). The posterior longitudinal costal strips are tapering from the posterior towards the anterior end (Fig. 14e). The costal strips forming the compound pedicel are exactly similar to these, yet turned upside down. It is tempting to speculate that the cell, when assembling its lorica, has at its disposal a total of seven posterior longitudinal costal strips, which in this species equals the common denominater for lorica components. The seven costal strips are typically distributed with two or three costal strips entering the compound pedicel, and the remaining four or five costal strips forming the posterior lorica chamber. While the distribution was 3:4 in the type material (Booth 1990), we have encountered mostly specimens with a 2:5 distribution (Fig. 14e, h). Notice 
that in Fig. 14e one posterior longitudinal costal strip is doubled. No anterior unilateral spines

421 have so far been reported for PI. tricaudata.

Distribution: Previously recorded from the subarctic Pacific Ocean (Booth 1990), central

Californian waters, USA (Thomsen et al. 1991), Sydney Harbour, Australia (Tong et al. 1998), St.

Lawrence, Canada (Bérard-Therriault et al. 1999), New Zealand (Moestrup, unpublished results), and Beagle Channel, Patagonia (Thomsen, unpublished results). Here we report findings of $P$. tricaudata from the Gulf of California (Table 1).

\section{Parvicorbicula Deflandre, 1960}

Within the genus Parvicorbicula (replacement name for Corbicula Meunier, 1910), the situation

431 is quite the opposite of what applies to Pleurasiga. We are here confronted with a well-defined

432 type species, $P$. socialis (Meunier, 1910) Deflandre, 1960 (Fig. 3k), that despite being first

433 described using light microscopy only (Meunier 1910), has been convincingly redefined using 434 electron microscopical techniques (e.g. Buck 1981; Manton et al. 1976; Thomsen 1973). It is 435 additionally possible to select a handful of species of Parvicorbicula (i.e. P. quadricostata 436 Throndsen, 1970 (Fig. 3l); P. circularis Thomsen, 1976 (Fig. 3m); P. corynocostata Thomsen, 437 Garrison and Kosman, 1997 (Fig. 3n), and possibly also P. manubriata Tong, 1997 (Fig. 3o)) that, 438 from a morphological point of view, form a fairly well-defined cluster (core group of species) in 439 association with the type species. In these species there are 4-10 longitudinal costae and two 440 transverse costae, one of which closes the lorica anteriorly.

441 The genus additionally comprises (Fig. 3p-x) eight species (i.e. Pa. pedicellata Leadbeater, 1973 442 (Fig. 3p); Pa. serrulata Leadbeater in Manton et al., 1975 (Fig. 3q); Pa. pedunculata Leadbeater, 
1980 (Fig. 3r); Pa. ongulensis Takahashi, 1981 (Fig. 3s); Pa. superpositus Booth, 1990 (Fig. 3t); Pa. zigzag Thomsen in Thomsen et al., 1991 (Fig. 3u); Pa. pachycostata Thomsen in Thomsen et al., 1997 (Fig. 3v), and Pa. aculeatus Tong, 1997 (Fig. 3x)) that have been placed here in the lack of better choices and also in consideration of not establishing too many monotypic genera while in the process of describing basic loricate choanoflagellate diversity. A redefinition of the genus Parvicorbicula focusing in particular on the core group of species will thus leave us with a large contingent of species that will have to be moved elsewhere. Molecular data only exist for Pa. pedunculata (Nitsche et al. 2011) and show that this species is phylogenetically far removed from both PI. minima and PI. reynoldsii (Nitsche et al. 2017). It currently clusters with species of Acanthocorbis and Stephanoeca which is not completely unexpected based on elements of similarity in certain lorica features.

Parvicorbicula zigzag is the only Parvicorbicula species that is abundantly present in warm water habitats. This species deviates markedly from the core species of Parvicorbicula. It is, however, from a lorica constructional point of view almost identical to Stephanacantha parvula Thomsen in Thomsen and Boonruang, 1983. Despite the fact that Stephanacantha as presently circumscribed (Thomsen and Boonruang 1983) comprises only species with flattened and elaborate costal strips, it is likely that in a phylogenetic perspective lorica constructional details will be more decisive than the actual elaboration of the individual costal strip. A formal transfer of Pa. zigzag to the genus Stephanacantha is planned for the next following publication in this series. Two further species, viz. Pa. pedicellata (Fig. 3p) and Pa. superpositus (Fig. 3t), were commonly observed but are better dealt with in a later publication that focuses on taxa with free anterior spines. 
Parvicorbicula socialis (Meunier, 1910) Deflandre, 1960 (Fig. 3k, 15a)

This is the type species of the choanoflagellate genus Corbicula Meunier, 1910. However, due to the fact that the genus name was preoccupied (Corbicula Mergerle, 1811), Deflandre (1960) later provided a substitute name (Parvicorbicula Deflandre, 1960) for the loricate choanoflagellate taxon.

The funnel-shaped lorica comprises 10 longitudinal costae and two transverse costae. Only solitary specimens were observed.

Distribution: Very frequently reported at latitudes $>40^{\circ}$ North and South. Parvicorbicula socialis becomes a community dominant species at high latitudes in both hemispheres and is often forming huge colonies (Escalera et al. 2019). The number of previous recordings from warm water habitats are extremely sparse comprising only Lyons, Mediterranean Sea (Pavillard 1917), the Cape Town region, S. Africa (Manton et al. 1976), and the Red Sea (Thomsen 1978). Here we report the species from West Australia only (Table 1).

\section{Parvicorbicula circularis Thomsen, 1976 (Fig. 3m, 15b-e)}

Parvicorbicula circularis is closely related to Pa. quadricostata Throndsen, 1970 . However, in this species the mid-lorica transverse costa is square and comprising only four costal strips (Throndsen 1970). In Pa. circularis the mid-lorica transverse costa is circular comprising 6-8 transverse costal strips (Thomsen 1976; Thomsen et al. 1990). The specimens reported on here all possess two equally large transverse costae (Fig. 15b-e).

Distribution: Previously recorded from Danish coastal waters (Thomsen 1976; Thomsen et al. 2016): the Baltic Sea proper (Thomsen 1979); Lützow-Holm Bay, Prydz Bay, Davis, King George Island, Weddell Sea, Antarctica (Buck and Garrison 1988; Chen 1994; Marchant 1985; Marchant 
and Perrin 1990; Takahashi 1981; Thomsen et al. 1991); the Subarctic North Pacific (Booth 1990); central Californian waters (Thomsen et al. 1991); Disko Bay, North East Water, Greenland (Thomsen and $\emptyset$ stergaard 2017; Thomsen et al. 1995); the equatorial Pacific Ocean (Vørs et al. 1995); Southampton, UK (Tong 1997b); Newfoundland, Canada (McKenzie et al. 1997); Shark Bay and Sydney Harbour, Australia (Tong 1997a; Tong et al. 1998); Beagle Channel, Patagonia (Thomsen, unpublished). Here we report findings of $P a$. circularis from five out of seven regions sampled (Table 1).

\section{Discussion}

It is evident from the above that the current taxonomy of both Pleurasiga and Parvicorbicula is confused and in need of revision. In an attempt to circumscribe morphologically, and hence also phylogenetically, well-defined core group species selected from both genera, Leadbeater (2015) listed the following taxa: Parvicorbicula socialis, Pa. quadricostata, Pa. circularis, Pa. corynocostata, Pleurasiga minima, $P$ I. reynoldsii, and PI. tricaudata as being distinct from the majority of other tectiform species based on that they have both the anterior and, more significantly, the lower transverse costa on the outer surface of the lorica. This cluster of species shares additional lorica features, i.e. longitudinal costae composed of three costal strips, two transverse costae (an anterior ring and a second transverse costa at the join between the second and third longitudinal costal strip), a membrane enveloping the protoplast and suspended from the free posterior tips of the middle layer longitudinal costal strips, anterior 'T-junctions' between longitudinal and transverse costal strips, and a flattened and slightly biforked termination of the tip of the anterior longitudinal costal strips. Leadbeater (2015) further adds Pl. echinocostata to the core group of species listed above, despite the absence of a mid-lorica transverse costa in this 
species, but with reference to a great overall similarity with PI. minima. Also Pa. corynocostata and Pa. manubriata are identified as potential members of this clustering despite minor differences in

513 lorica features.

514 There is little doubt that the grouping of species as suggested by Leadbeater (2015), although 515 likely with minor modifications, will eventually also be supported by molecular evidence. Moving 516 all species of Pleurasiga, with the exception of the type species Pl. orculaeformis, to the genus 517 Parvicorbicula will solve the Pleurasiga enigma by leaving this as a monotypic genus. However, a 518 redefinition of the genus Parvicorbicula as indicated above, to accommodate only a small selection 519 of species from both genera, will as previously pointed out, leave many additional species in 520 jeopardy. Despite basically agreeing with the view put forward by Leadbeater (2015) we are 521 inclined to take a conservative approach here while awaiting (1) further morphological analyses of 522 any single species from the cluster of outskirt species of Parvicorbicula (to enable qualified 523 decisions about their future positioning in the morphospecies matrix), and (2) molecular evidence 524 that can support the choice of classification scheme.

525 The finding of reversed patterns of costal strip junctions in Pl. minutissima sp. nov., when 526 comparing with the generalized picture as outlined by Leadbeater (2015), is exceptional and 527 unexpected. We are painfully aware of that we have in the past had to deal with mirror-image 528 issues in part of the material collected from warm water habitats and examined using different 529 microscopes (Thomsen and $\varnothing$ stergaard 2019d) resulting in a decision to flip images from one 530 particular microscope horizontally. While this produced images of e.g. Cosmoeca that from a 531 constructional point of view confirmed previous observations, and thus also corroborated the 532 general picture as outlined by Leadbeater (2015), it did at the same time produce images of $P$. 533 minutissima that clearly have a reversed symmetry. Fortunately, we have been able to verify, 
based on SEM and TEM images from alternative sources (Fig. 13a-c), that this is in fact the general picture in this species. It is tempting to speculate that the reversed pattern is somehow connected to the fact that the mid-lorica transverse costa is exterior relative to the longitudinal costae. Other species that share this feature with Pl. minutissima, i.e. the external positioning of both transverse costae, have '4-point' abutting joints at the level of the mid-lorica transverse costa. This means that a transverse costal strip stretches from one longitudinal costa to the next without much overlap, and without leaving many options for a detailed study of any repetitiveness in costal strip joint patterns. From a purely morphological point of view PI. minutissima is much similar to PI. minima. A search for images of PI. minima (also from outside the warm water habitats) that would at least allow for a preliminary inter-specific comparison of costal strip patterns at the level of the mid-lorica transverse costa, has resulted in the finding of a few specimens, in which the '4-point'

545 abutting joints are slightly more elaborate than just abutting. The pattern observed is illustrated 546 here based on material from Danish coastal waters (Fig. 16). The enlarged lorica segment (Fig. 547 16a) and the schematic drawing (Fig. 16c), show the lorica joint patterns as seen from both the 548 outside and the inside of the lorica. The mid-lorica transverse costa is obviously external relative 549 to the longitudinal costa, and the left-hand end of a transverse costal strip, when viewed in a 550 clockwise direction, clearly underlaps the neighboring strip and also projects beyond the 551 longitudinal costal strip indicating that this is where the artificial triangle would form in case the 552 costal strip overlaps had been any larger. This is thus basically the same pattern as observed in Pl. 553 minutissima. It is unclear to us how profound this difference in symmetry of costal strip patterns 554 is, and also what sort of consequences this will have with reference to e.g. our understanding of 555 lorica formation principles and hence also our morphospecies based loricate choanoflagellate 
classification schemes. An essential additional question that needs to be addressed is what are the possible relative benefits of a transverse costa being inside or outside the lorica chamber.

Costal strips comprising the longitudinal costae of Pleurasiga species overlap each other from

the posterior forwards and thus confirms to the general pattern as detailed by Leadbeater (2015).

The overlap between longitudinal costal strip one and two is particularly evident in most species and morphotypes (except in PI. echinocostata form B) and provides points of attachment for the membranous sheath that surrounds the protoplast and part of the collar.

A final major point to address here is the finding that a right-hand positioning of the anterior spine on anterior transverse costal strips (when viewed from the outside of the lorica) appears to be a universal feature of species of Pleurasiga (here documented for Pl. echinocostata, Pl. minima and PI. minutissima). A literature search has already confirmed the generality of this lorica feature in Pl. echinocostata and Pl. minima (see above). Manton et al. (1976; loc. cit. Figs 61, 62) documented that also in PI. reynoldsii the anterior transverse costal strips may occasionally carry minute spines at the right-hand of a costal strip, when viewed from the outside of the lorica.

\section{Author contribution statement}

Helge A. Thomsen (HAT) has undertaken a major part of the sampling activities and the sampling. JBO has also carried out part of the transmission electron microscopical examination of these samples. Nina A. Kamennaya (NAK) and Mikhail V. Zubkov (MVZ) have provided SEM images of Pl. minutissima and commented on the drafts of the manuscript. 


\section{Acknowledgements}

Crew and scientists on board the research vessels ('Dana', 'Vaedderen', 'Chakratong Tongyia', 'Malcolm Baldrige', 'Sonne', 'Discovery') are acknowledged for good collaborative spirit and for providing excellent facilities for collecting and processing our samples. Dr. Gunni /Ertebjerg and Steffen Mariager Pedersen are acknowledged for providing the samples from outside the Alexandria Harbour. We are grateful to Dr. Sergio Sanudo-Wilhelmy and Kurt Buck for organizing the trip to Gulf of California. Carol Kosman is warmly acknowledged for her meticulous contribution to this paper. Thanks are due to Dr. $\varnothing$. Moestrup (Univ. of Copenhagen) for letting us use his New Zealand specimen of PI. minutissima. We thank Drs. Tomasz Goral and Alex Ball from the Natural History Museum, London for support with the electron microscopy imaging. Thanks are due to an anonymous reviewer for providing valuable comments on major parts of the manuscript. Main funding sources, i.e. the Independent Research Fund Denmark, the Carlsberg Foundation, Danida (Denmark's development cooperation), the Højgaard Foundation, and the Danish Centre for Marine Research are acknowledged for their generous contributions to our research. The present work was carried out as part of the Galathea3 expedition under the auspices of the Danish Expedition Foundation (Galathea3 contribution no. P130), as part of the Sargasso-Eel 2014 Expedition, as part of the UltraPac Expedition on board Research Vessel Sonne (SO-245), and as part of the Transatlantic cruise on board the Royal Research Ship Discovery (DY084). The research on the cruises SO-245 and DY084 was supported by the UK Natural Environment Research Council through Research grant NE/M014363/1.

\section{References}


603 Bérard-Therriault, L., Poulin, M., Bossé, L., 1999 Guide d'identification du phytoplancton marin de 604 I'estuaire et du Golfe du Saint-Laurent incluant également certains protozoaires. Publ. spec. sci. 605 halieut. Aquat. 128, 1-387.

606 Booth, B.C., 1990. Choanoflagellates from the subarctic North Pacific Ocean, with description of 607 two new species. Can. J. Zool. 68, 2393-2402.

608 Buck, K., 1981. A study of choanoflagellates (Acanthoecidae) from the Weddell Sea, including a 609 description of Diaphanoeca multiannulata n. sp. J. Protozool. 28, 47-54.

610 Buck, K.R., Garrison, D.L., 1988. Distribution and abundance of choanoflagellates (Acanthoecidae) 611 across the ice-edge zone in the Weddell Sea, Antarctica. Marine Biol. 98, 263-269.

612 Chen, B., 1994. Distribution and abundance of choanoflagellates in Great-Wall Bay, King George 613 Island, Antarctica in austral summer. Proc. NIPR Symp. Polar Biol. 7, 32-42.

614 Daugbjerg, N., Vørs, N., 1994. Preliminary results from a small scale survey of marine protists from 615 Northern Foxe basin in the vicinity of Igloolik Island June 1992. In: Søeberg, B., Jensen, D., 616 Schurmann, H., Steffensen, J.F., Curtis, M.A., Vørs, N., Daugbjerg, N., Bushnell, P. (Eds.) 617 Research on Arctic biology Igloolik Northwest territories Canada. University of Copenhagen. 618 Deflandre, G., 1960. Sur la présence de Parvicorbicula n. g. socialis (Meunier) dans le plankton de 619 I'Antarctique (Terre Adélie). Revue Algologique, N.S., 5, 183-188, 620 Escalera, L., Mangoni, O., Bolinesi, F., Saggiomo, M., 2019. Austral summer bloom of loricate 621 choanoflagellates in the Central Ross Sea Polynya. J. Euk. Microbiol. 66, 849-852.

622 Espeland, G., Throndsen, J., 1986. Flagellates from Kilsfjorden, southern Norway, with description 623 of two new species of Choanoflagellida. Sarsia 71, 209-226. 
Hara, S., Sheu, J., Chen, Y.L., Takahashi, E., 1997. Choanoflagellates (Sarcomastigophora, Protozoa)

625 from the coastal waters of Taiwan and Japan (II): Species composition and biogeography. Zool. Stud. 36, 98-110.

Hoepffner, H., Haas, L.W., 1990. Electron microscopy of nanoplankton from the North Pacific central gyre. J. Phycol. 26, 421-439.

ICZN 1999. International Code of Zoological Nomenclature, Fourth Edition: The International Trust for Zoological Nomenclature,London, UK, 306 pp.

Kamennaya, N.A., Kennaway, G., Fuchs, B.M., Zubkov, M.V., 2018. “Pomacytosis” - Semiextracellular phagocytosis of cyanobacteria by the smallest marine algae. PLOS Biol. 16, e2003502, doi: 10.1371/journal.pbio.2003502.

Leadbeater, B.S.C., 1973. External morphology of some marine choanoflagellates from the coast of Jugoslavia. Arch. Protistenk. 115, 234-252.

Leadbeater, B.S.C., 2015. The Choanoflagellates: Evolution, biology and ecology. Cambridge University Press.

Leakey, R.J.G., Leadbeater, B.S.C., Mitchell, E., McCready, S.M.M., Murray, A.W.A., 2002. The abundance and biomass of choanoflagellates and other nanoflagellates in waters of contrasting

Manton, I., Sutherland, J., Leadbeater, B.S.C., 1976. Further observations on the fine structure of 645 marine collared flagellates (Choanoflagellata) from arctic Canada and west Greenland: species of Parvicorbicula and Pleurasiga. Can. J. Bot. 54, 1932-1955. 
Marchant, H.J. 1985. Choanoflagellates in the Antarctic marine food chain. In: Siegfried, W.R., Condy, P.R., Laws, R.M. (Eds.), Antarctic Nutrient Cycles and Food Webs. Springer-Verlag Berlin Heidelberg, pp. 271-276.

Marchant, H.J., Perrin, R., 1990. Seasonal variation in abundance and species composition of choanoflagellates (Acanthoecidae) at Antarctic coastal sites. Polar Biol. 10, 499-505.

McKenzie, C.H., Deibel, D., Thompson, R.J., MacDonald, B.A., Penney, R.W., 1997. Distribution and abundance of choanoflagellates (Acanthoecidae) in the coastal cold ocean of Newfoundland, Canada. Mar. Biol. 129, 407-416.

Menezes, S., 2005. Nanoplankton biodiversity in the Pettaquamscutt river estuary, Rhode Island, U.S.A. PhD thesis, Univ. Rhode Island, 319pp.

Meunier, A., 1910. Mikroplankton des Mers de Barents et de Kara. Duc d'Orleans: Campagne Arctique de 1907. Bruxelles.

Moestrup, $\varnothing ., 1979$. Identification by electron microscopy of marine nanoplankton from New Zealand, including the description of four new species. New Zeal. J. Bot. 17, 61-95.

Moestrup, $\varnothing$., Thomsen, H.A., 1980. Preparation of shadow-cast whole mounts. In: Gantt, E. (Ed.), Handbook of Phycological methods. Vol. III. pp. 385-390 (Cambridge).

Nitsche, F., Carr, M., Arndt, H., Leadbeater, B.S.C., 2011. Higher level taxonomy and molecular phylogenetics of the Choanoflagellatea. J. Eukaryotic Microbiol. 58, 452-462.

Nitsche, F., Thomsen, H.A., Richter, D.J., 2017. Bridging the gap between morphological species and molecular barcodes - exemplified by loricate choanoflagellates. Eur. J. Protistol. 57, 26-37. 
Schiller, J., 1925. Die planktonischen Vegetationen des Adriatischen Meeres. B. Chrysomonadina, Heterokontae, Cryptomonadina, Eugleninae, Volvocales. I. Systematischer Teil. Arch. Protistenk. 53, 59-123.

Sukhanova, I.N., 2001. Choanoflagellida on the southeastern Bering sea shelf. Oceanology 41, 227231.

Takahashi, E., 1981. Loricate and scale-bearing protists from Lützow-Holm Bay, Antarctica I. Species of the Acanthoecidae and the Centrohelida found at a site selected on the fast ice. Antarctic Record 73, 1-22.

Thomsen, H.A., 1973. Studies on marine choanoflagellates I. Silicified choanoflagellates of the Isefjord (Denmark). Ophelia 12, 1-26.

Thomsen, H.A., 1976. Studies on marine choanoflagellates. II. Fine structural observations on some silicified choanoflagellates from the Isefjord (Denmark), including the description of two new species. Norw. J. Bot. 23, 33-51.

Thomsen, H.A., 1978. Nanoplankton from the Gulf of Elat (= Gulf of Aquaba), with particular emphasis on the choanoflagellates. Isr. J. Zool. 27, 34-44.

Thomsen, H.A., 1979. Electron microscopical observations on brackish-water nannoplankton from the Tvärminne area, S.W. Coast of Finland. Acta Bot. Fenn. 110, 11-37.

Thomsen, H.A., 1982. Planktonic choanoflagellates from Disko Bugt, West Greenland, with a survey of the marine nanoplankton of the area. Meddr. Grønland, Bioscience 8, 1-35.

Thomsen, H.A., Boonruang, P., 1983. A microscopical study of marine collared flagellates (Choanoflagellida) from the Andaman Sea, SW Thailand: Species of Stephanacantha gen. nov. and Platypleura gen. nov. Protistologica 19, 193-214. 
691 Thomsen, H.A., Buck, K.R., 1991. Choanoflagellate diversity with particular emphasis on the Acan692 thoecidae. In: Patterson, D.J., Larsen, J. (Eds.), Free-living heterotrophic flagellates. Clarendon 693 Press, Oxford, pp. 259-284.

694 Thomsen, H.A., Larsen, J., 1992. Loricate choanoflagellates of the Southern Ocean with new 695 observations on cell division in Bicosta spinifera (Throndsen, 1970) from Antarctica and Saroeca 696 attenuata Thomsen, 1979, from the Baltic Sea. Polar Biol. 12, 53-63.

697 Thomsen, H.A., Østergaard, J.B., 2017. Acanthoecid choanoflagellates from the Atlantic Arctic 698 region - a baseline study. Heliyon 3 (2017) e00345 doi: 10.1016/j.heliyon.2017. e00345 699 Thomsen, H.A., Østergaard, J.B., 2019a. Loricate choanoflagellates (Acanthoecida) from warm $700 \quad$ water seas. I. Conioeca gen. nov. and Nannoeca Thomsen. Eur. J. Protistol. 67, 77-88.

701 Thomsen, H.A., Østergaard, J.B., 2019b. Loricate choanoflagellates (Acanthoecida) from warm 702 water seas. II. Bicosta, Apheloecion, Campyloacantha and Saroeca. Eur. J. Protistol. 67, 114-131. 703 Thomsen, H.A., Østergaard, J.B., 2019c. Loricate choanoflagellates (Acanthoecida) from warm 704 water seas. III. Acanthocorbis Hara and Takahashi and Stephanoeca Ellis. Eur. J. Protistol. 69, $705 \quad 52-69$.

706 Thomsen, H.A., Østergaard, J.B., 2019d. Loricate choanoflagellates (Acanthoecida) from warm 707 water seas. IV. Cosmoeca Thomsen. Eur. J. Protistol. 71, article 125632.

708 Thomsen, H.A., Østergaard, J.B., 2019e. Loricate choanoflagellates (Acanthoecida) from warm 709 water seas. V. Thomsenella Özdikmen (= Platypleura Thomsen). Eur. J. Protistol. 71, article $710 \quad 125633$.

711 Thomsen, H.A., Buck, K.R., Coale, S.L., Garrison, D.L., Gowing, M.M., 1990. Loricate 712 choanoflagellates (Acanthoecidae, Choanoflagellida) from the Weddell Sea, Antarctica. Zool. 713 Scr. 19, 367-387. 
714 Thomsen, H.A., Buck, K.R., Chavez, F.P., 1991. Choanoflagellates of the central California waters:

715 Taxonomy, morphology and species assemblages. Ophelia 33, 131-164.

716 Thomsen, H.A., Østergaard, J.B., Hansen, L.E., 1995. Loricate choanoflagellates from West

717 Greenland (August 1988) including the description of Spinoeca buckii gen. et sp. nov. Eur. J.

$718 \quad$ Protistol. 31, 38-44.

719 Thomsen, H.A., Garrison, D.L., Kosman, C., 1997. Choanoflagellates (Acanthoecidae,

720 Choanoflagellida) from the Weddell Sea, Antarctica, taxonomy and community structure with

721 particular emphasis on the ice biota; with preliminary remarks on choanoflagellates from Arctic

722 sea ice (Northeast Water Polynya, Greenland). Arch. f. Protistenk. 148, 77-114.

723 Thomsen, H.A., Nitsche, F., Richter, D.J., 2016. Seasonal occurrence of loricate choanoflagellates in 724 Danish inner waters. Protist 167, 622-638.

725 Throndsen, J., 1970. Marine planktonic Acanthoecaceans (Craspedophyceae) from Arctic waters. $726 \quad$ Nytt Mag. Bot. 17, 103-111.

727 Throndsen, J., 1974. Planktonic choanoflagellates from North Atlantic waters. Sarsia 56, 95-122.

728 Tong, S.M., 1997a. Heterotrophic flagellates from the water column in Shark Bay, Western

729 Australia. Mar. Biol. 128, 517-536.

730 Tong, S.M., 1997b. Choanoflagellates in Southampton Water including the description of three 731 new species. J. Mar. Biol. Ass. U.K. 77, 929-958.

732 Tong, S.M., Nygaard, K., Bernard, C., Vørs, N., Patterson, D.J., 1998. Heterotrophic flagellates from 733 the water column in Port Jackson, Sydney, Australia. Eur. J. Protistol. 34, 162-194.

734 Vørs, N., Buck, K.R., Chavez, F.P., Eikrem, W., Hansen, L.E., Østergaard, J.B., Thomsen, H.A., 1995. 735 Nanoplankton of the equatorial Pacific with emphasis on the heterotrophic protists. Deep-Sea 736 Research 42, 585-602. 


\section{Legends}

Fig. 1. Map showing the approximate sampling sites for material reported here and MODIS sea surface temperatures (2003-2011 average). A circular dot refers to a single spot sampling, while a line or square indicates that samples were collected along extended transects (for further information see the materials and methods section in Thomsen and Østergaard (2019a)).

Fig. 2. Pleurasiga minima TEM whole mount labelled to introduce loricate choanoflagellate terminology. Micrograph from central Californian waters (RV 'Point Sur' cruise; see Thomsen et al. 1991).

Fig. 3.a-x. Drawings to approximate scale of Pleurasiga and Parvicorbicula species. (a) Pleurasiga orculaeformis (type species); (b) Pl. minima; (c) Pl. minutissima sp. nov.; (d) Pl. reynoldsii; (e) Pl. tricaudata; (f) Pl. echinocostata; (g) Pl. echinocostata form A; (h) Pl. echinocostata form B; (i, j) Pl. quadrangiella sp. nov.; (k) Pa. socialis (type species); (I) Pa. quadricostata; (m) Pa. circularis; (n) Pa. corynocostata; (o) Pa. manubriata; (p) Pa. pedicellata; (q) Pa. serrulata; (r) Pa. pedunculata; (s) Pa. ongulensis; (t) Pa. superpositus; (u) Pa. zigzag; (v) Pa. pachycostata; (x) Pa. aculeatus.

Fig. 4.a-q. Pleurasiga echinocostata TEM (a) and LM (b-l; phase contrast, except $\mathrm{h}(\mathrm{NIC})$ ) and $P$. echinocostata form A TEM (q) and LM (m-p) whole mounts from the Gulf of California (a-c), the Sargasso Sea (d-f), the equatorial Pacific Ocean (g), the Andaman Sea (h, q), West Australia (i-k, mp), and the Caribbean Sea (I). (a) Empty lorica (reversed printing) showing basic lorica features; notice the posterior membrane which is suspended by the protruding tips of longitudinal costal strips; (b-I) Selected light micrographs to illustrate the diversity encountered when examining 
specimens from a wide range of localities under low magnification; (m-p) Aberrant forms ( $P$. echinocostata form A) encountered in samples from West Australia; (q) Complete lorica of form A specimen; notice the anterior spines and the overlap between middle lorica longitudinal costal strips. The scale bar (h) applies to all LM images.

Fig. 5.a-e. Pleurasiga echinocostata $(a, b)$ and P. echinocostata form B (c-e) SEM (a) and TEM (b-e) whole mounts from Danish coastal waters (a), the Andaman Sea, Thailand (b, $d, e)$ and the equatorial Pacific Ocean (c). (a) Anterior transverse costa showing details of spines and the attachment between transverse and longitudinal costal strips; (b) High magnification (reversed printing) of a single transverse costal strip viewed from the outside of the lorica; (c-e) Complete form B loricae; notice the absence of both spines and extended costal strip overlaps in the lower mid lorica region; reversed printing (d).

Fig. 6. Graph illustrating the relationship between lorica height and the diameter of the anterior transverse costa, as well as differences between geographic regions sampled in Pleurasiga echinocostata sensu stricto (circular markers) and Pl. echinocostata form A (square markers).

Fig. 7.a-i. Pleurasiga quadrangiella TEM (a, c) and LM (b, d-i; phase contrast except b (NIC)) whole mounts from the Andaman Sea (a-c), West Australia (d-g), and the Equatorial Pacific Ocean (h, i). (a) Complete cell (holotype) with protoplast, collar and flagellum; (b, d-i) Selected specimens to show the morphological variability encountered; (c) Empty lorica showing costal strip details; notice the membrane that envelopes the protoplast; costal strips terminating the lorica posteriorly are limited in number (2). The scale bar (i) applies to all light micrographs. 
786 Fig. 8.a-b. Pleurasiga quadrangiella TEM micrographs from the Andaman Sea, Thailand. (a)

787 Complete cell with protoplast, collar and a well-defined posterior transverse costa; (b) Detail from 788 a (reversed printing); the arrow points to costal strip junction where the transverse costal strips 789 are unmistakably inside the longitudinal costae; the arrowhead marks a transverse costal strip 790 located between a proximal (to the right) and a distal (to the left) longitudinal costa.

792 Fig. 9.a-p. Pleurasiga minima TEM (a), SEM (j) and LM (b-i, k-p; phase contrast except b (NIC)) 793 whole mounts from the Andaman Sea, Thailand (a, b, j), the Sargasso Sea (c, e), the Gulf of 794 California, Mexico (d), West Australia (f-h), the Caribbean Sea (i, k), and the equatorial Pacific 795 Ocean (I-p). (a) Details of lorica; notice that the seven longitudinal costae meet posteriorly; (b-i, kp) Selected specimens to show the morphological variability encountered; (j) Detail of anterior transverse and longitudinal costal strips viewed from the inside of the lorica. The scale bar (g) applies to all light micrographs.

Fig. 10.a-d. Diagrams illustrating (a) the PI. minima site-specific relationship between the diameter of the anterior transverse costa (x-axis) and the mid-lorica transverse costa (y-axis); (b) the PI. minutissima site-specific relationship between the diameter of the anterior transverse costa ( $\mathrm{x}$ axis) and the mid-lorica transverse costa (y-axis); (c) lorica height in PI. minima and PI. minutissima; (d) a comparison between PI. minima and Pl. minutissima (diameter of anterior transverse costa versus diameter of mid-lorica transverse costa); notice the well-defined slopes of the trend lines calculated. 
Fig. 11.a-q. Pleurasiga minutissima TEM (a, b, i, q) and LM whole mounts (c-h, j-p; phase contrast) from the Andaman Sea (a), the Gulf of California (b, h, i, m), the Sargasso Sea (c, f, g), West Australia (d, j-I, n-p), the Caribbean Sea (e), and the equatorial Pacific Ocean (q). (a, b, i) Complete cells showing details of lorica construction; the encircled areas (a) show costal strip junctions as seen from the outside of the lorica; arrows (b) show costal strip junctions as seen from the inside of the lorica; (c-h, j-p) Selected micrographs to show the morphological variability encountered;

(q) High magnification of anterior costal strips to show the spines on transverse strips and the bifurcated termination of the longitudinal strip. Notice that one transverse costal strip quite unusually has been completely turned around so that two spines appear together. The scale bar (c) applies to all light micrographs.

Fig. 12.a-i Pleurasiga minutissima TEM (a-c) and LM whole mounts (d-i; phase contrast) from the equatorial Pacific Ocean. (a-c) Complete cells documenting costal strip features; (d-i) Selection of micrographs showing the variability encountered. The scale bar (i) applies to all light micrographs.

Fig. 13.a-c. Pleurasiga minutissima TEM (a) and SEM (b, c) micrographs from New Zealand (a; courtesy of $\varnothing$ jvind Moestrup) and the South Atlantic (b) and South Pacific (c) oceans; (a) Reverse printing of a complete cell; the arrowheads point to proximal longitudinal costae, and the arrows to distal longitudinal costae; costal strip junctions as seen from the outside (thick line) and inside of the lorica (thin line) are encircled; see text for further explanation; (b) Complete lorica with intact protoplast; the arrows point to costal strip junctions in the mid-lorica transverse costa viewed from the inside of the lorica; the arrowhead points to an intact costal strip junction viewed from the outside of the lorica; notice also the short posterior pedicel and the external position of 
832

the mid-lorica transverse costa relative to the longitudinal costae; (c) Complete cells of PI. minutissima (right) and Cosmoeca ventricosa form B (left); costal strip junctions in the mid-lorica transverse costa as viewed from the outside of the lorica are mirror images and encircled ( $P$. minutissima) or framed by rectangles (C. ventricosa form B).

Fig. 14.a-h. Pleurasiga reynoldsii (a-d) and Pl. tricaudata (e-h), LM (a-d, f, g; phase contrast), SEM (e), and TEM (h) whole mounts from the Gulf of California (a, f-h), West Australia (b), the Sargasso Sea (c), the equatorial Pacific Ocean (d), and the South Atlantic Ocean (e); (a-d) Selection of PI. reynoldsii LM images to show the variability encountered; notice the pronounced size variability; (e) Cell documenting basic costal strip and lorica features; notice the exterior positioning of both transverse costae and the costal strip junctions (arrows); (f, g) Light microscopical images of Pl. tricaudata; (h) Cell with protoplast documenting basic lorica features; the arrow points to a biforked tip on a posterior lorica chamber costal strip. The scale bar (c) applies to all LM micrographs.

Fig. 15. a-e. Parvicorbicula socialis (a) and Pa. circularis (b-e) LM whole mounts (phase contrast) from West Australia (a, e), the Caribbean Sea (b), and the Gulf of California (c, d). (a) Single specimen documenting the rare occurrence of $P a$. socialis in warm water habitats; (b-e) Differently sized specimens of Pa. circularis. The scale bar (c) applies to all LM micrographs.

Fig. 16.a-c. Pleurasiga minima TEM whole mounts from Danish coastal waters; (a) High magnification of lorica details from (b) to show costal strip junctions as appearing from both the outside and the inside of the lorica; (c) Schematic drawings of the junctions between transverse 
855 and longitudinal costal strips; the labelling is identical to that used by Leadbeater (2015) where (a) 856 is the transverse costal strip that terminates at the longitudinal costa, (b) denotes the overlapping 857 transverse costal strip, and (c, d) the longitudinal costal strips.

858

859

860

861

862

863

864

865

866

867

868

869

870

871

872

873

874

875

876

877

878 
879 Table 1. Occurrence pattern of species discussed here and in Thomsen and Østergaard (2019a-e).

880 New species described in Thomsen and Østergaard (2019a-e) are marked with *.

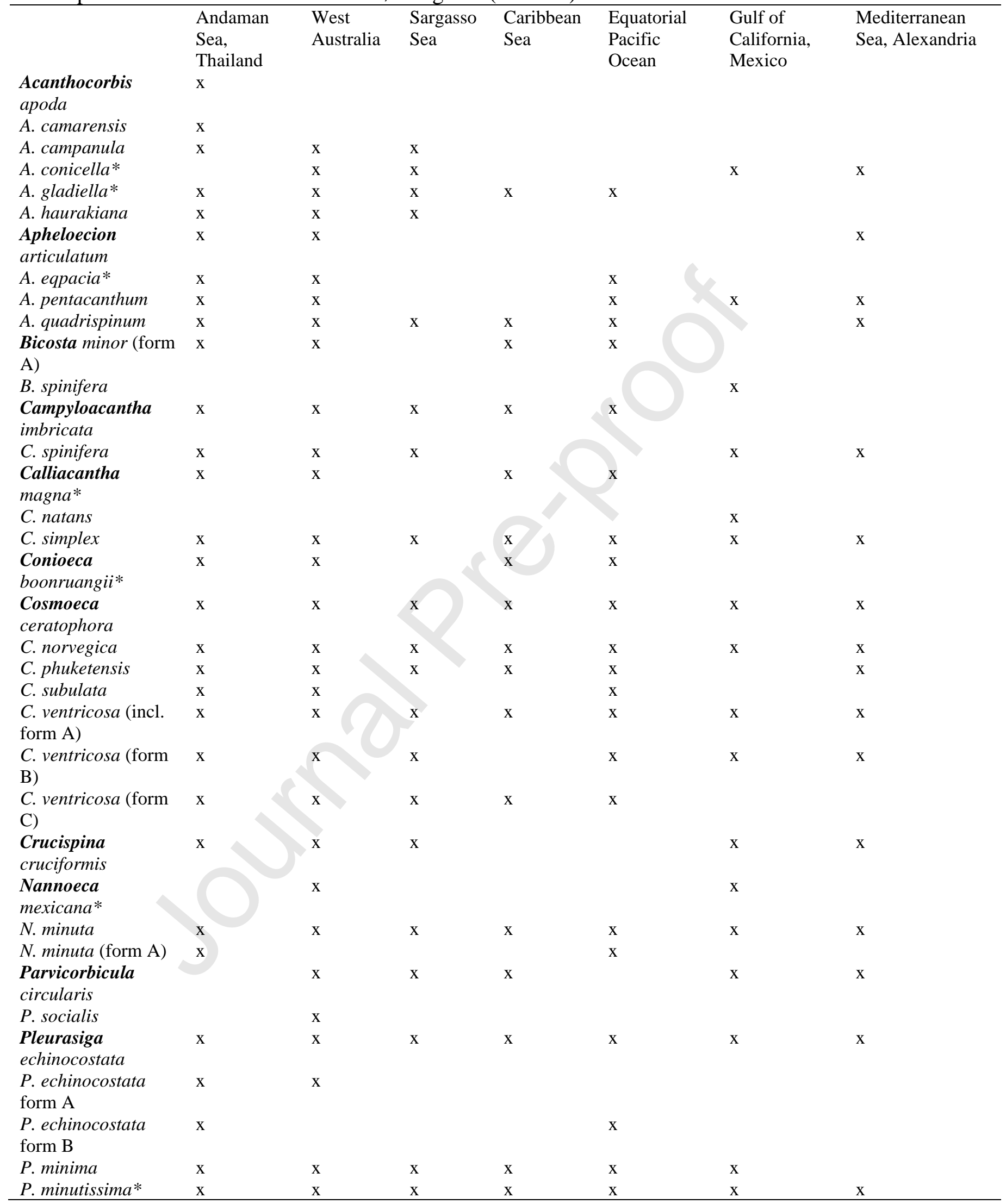




\begin{tabular}{|c|c|c|c|c|c|c|c|}
\hline P. quadrangiella* & $\mathrm{x}$ & $\mathrm{x}$ & & & $\mathrm{x}$ & & \\
\hline P. reynoldsii & & $\mathrm{x}$ & $\mathrm{x}$ & & $\mathrm{x}$ & $\mathrm{x}$ & \\
\hline P. tricaudata & & & & & & $\mathrm{x}$ & \\
\hline Saroeca attenuata & & & $\mathrm{x}$ & & $(\mathrm{x})$ & & \\
\hline S. paucicostata & $\mathrm{x}$ & $\mathrm{x}$ & $\mathrm{x}$ & & & $\mathrm{x}$ & $\mathrm{x}$ \\
\hline $\begin{array}{l}\text { Stephanoeca } \\
\text { andemanica* }\end{array}$ & $\mathrm{x}$ & $\mathrm{x}$ & & & & & \\
\hline S. apheles & $\mathrm{x}$ & $\mathrm{x}$ & & & & & \\
\hline S. broomia* & $\mathrm{x}$ & $\mathrm{x}$ & & & & & \\
\hline $\begin{array}{l}\text { S. diplocostata var. } \\
\text { paucicostata }\end{array}$ & & $\mathrm{x}$ & & & & & \\
\hline S. naja* & $\mathrm{x}$ & $\mathrm{x}$ & $\mathrm{x}$ & & $\mathrm{x}$ & $\mathrm{x}$ & \\
\hline S. supracostata & $\mathrm{x}$ & & & & & & \\
\hline Thomsenella acuta & $\mathrm{x}$ & $\mathrm{x}$ & $\mathrm{x}$ & $\mathrm{x}$ & $\mathrm{x}$ & & $\mathrm{x}$ \\
\hline T. cercophora & $\mathrm{x}$ & $\mathrm{x}$ & & & $\mathrm{x}$ & & $\mathrm{x}$ \\
\hline T. infundibuliformis & & & $\mathrm{x}$ & & $\mathrm{x}$ & $\mathrm{x}$ & $\mathrm{x}$ \\
\hline T. perforata & $\mathrm{x}$ & $\mathrm{x}$ & $\mathrm{x}$ & $\mathrm{x}$ & $\mathrm{x}$ & $\mathrm{x}$ & $\mathrm{x}$ \\
\hline
\end{tabular}

881 


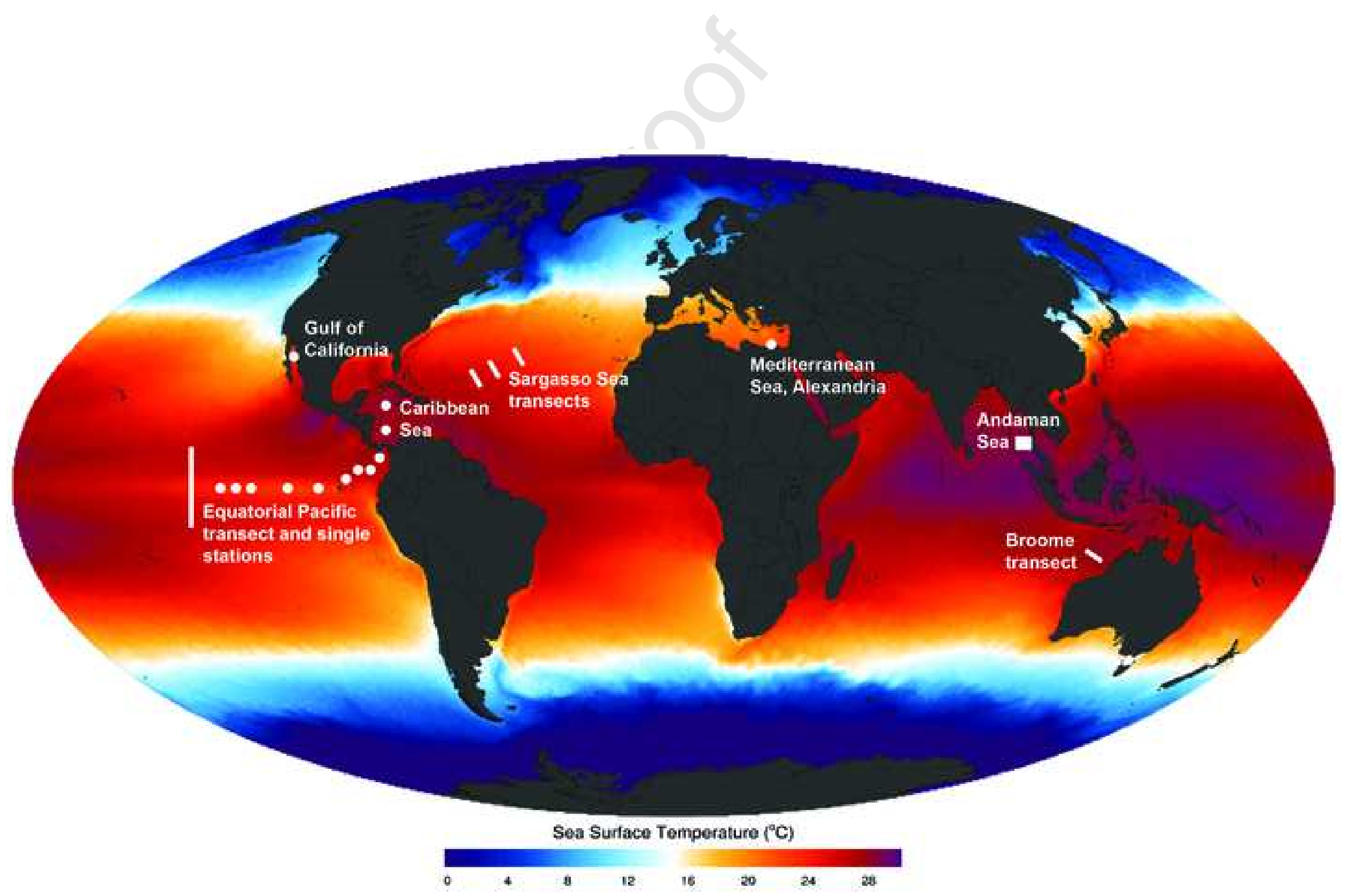




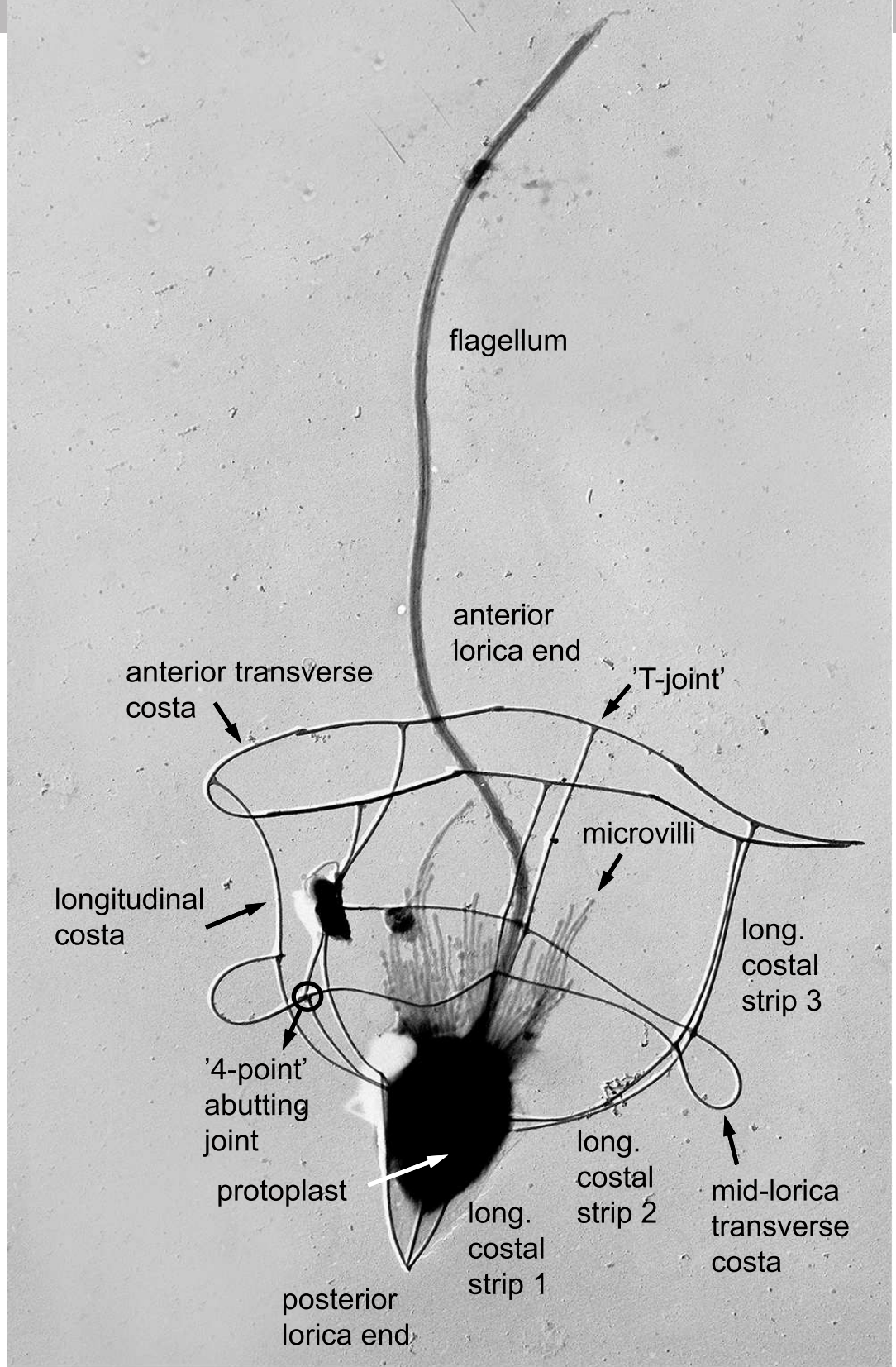



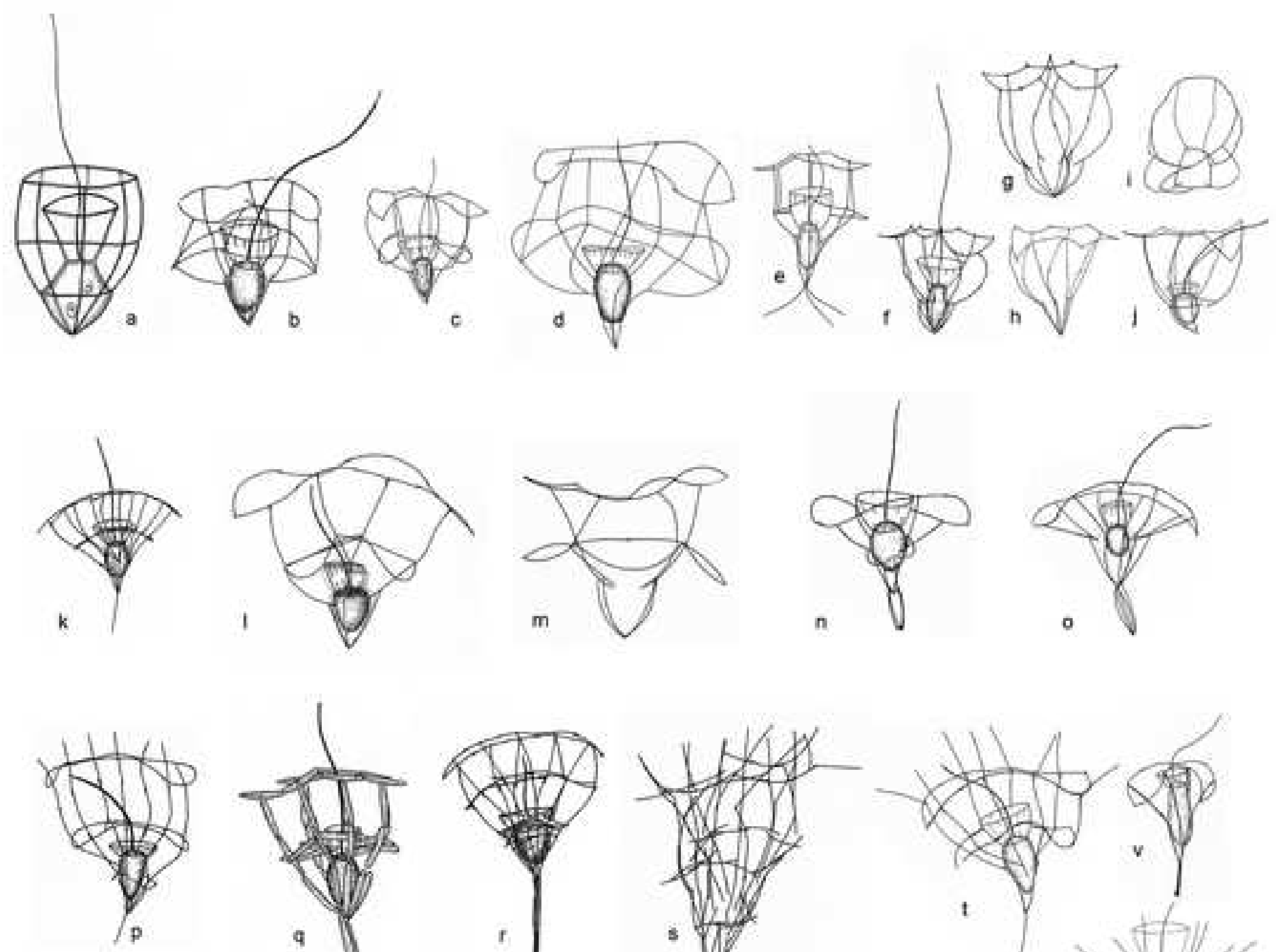

$10 \mu \mathrm{m}$
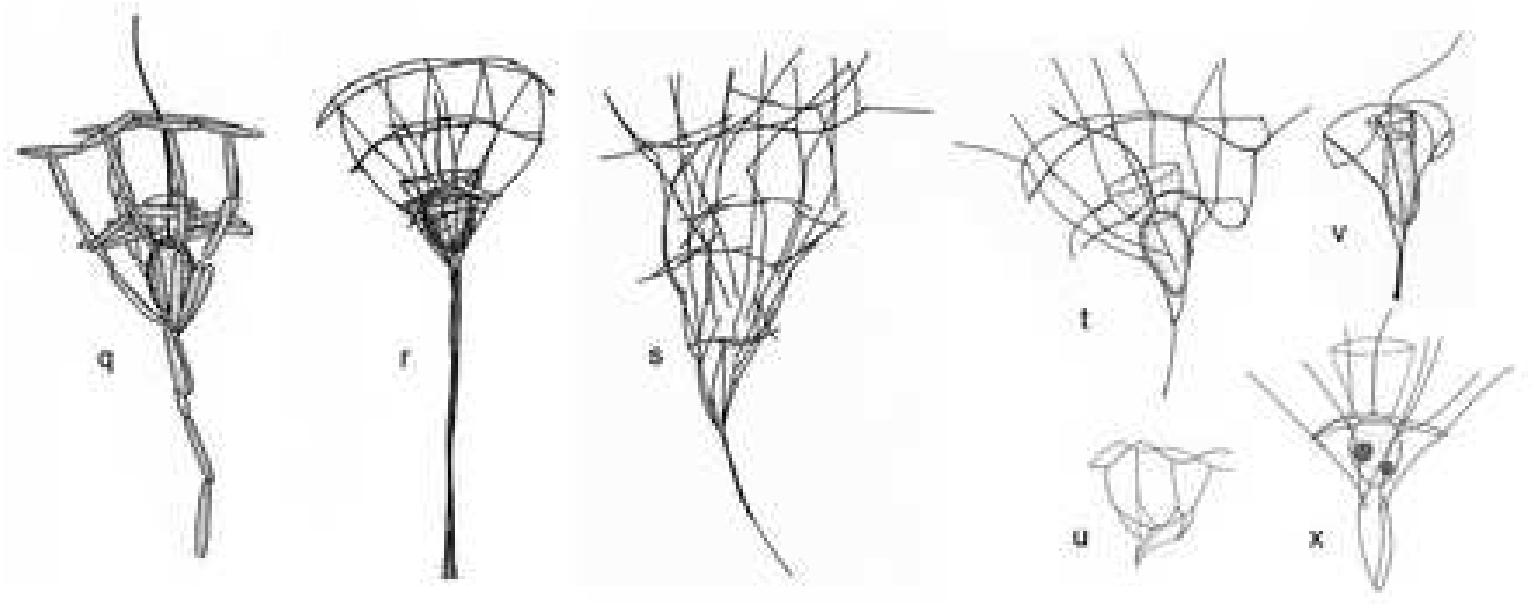

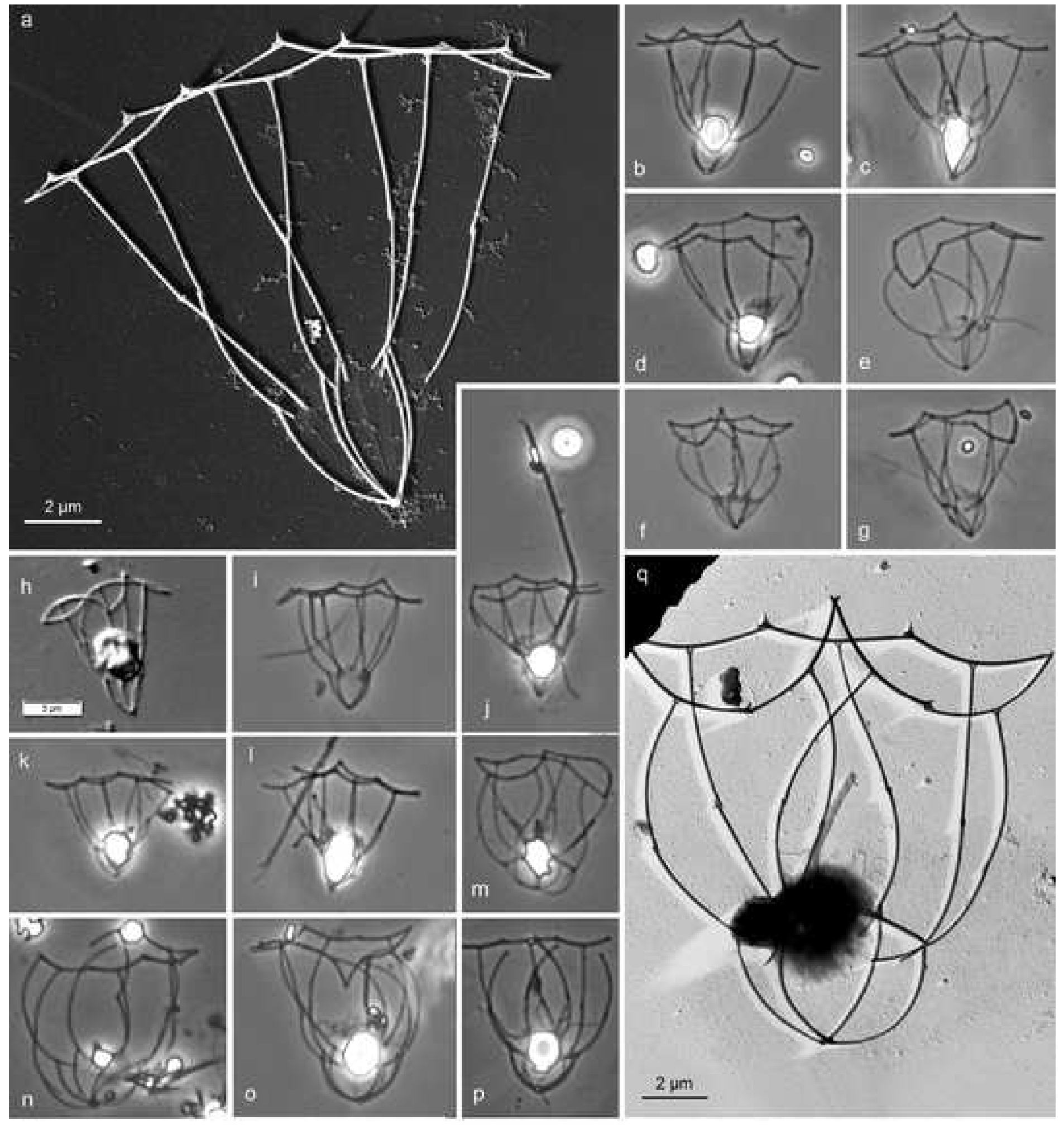

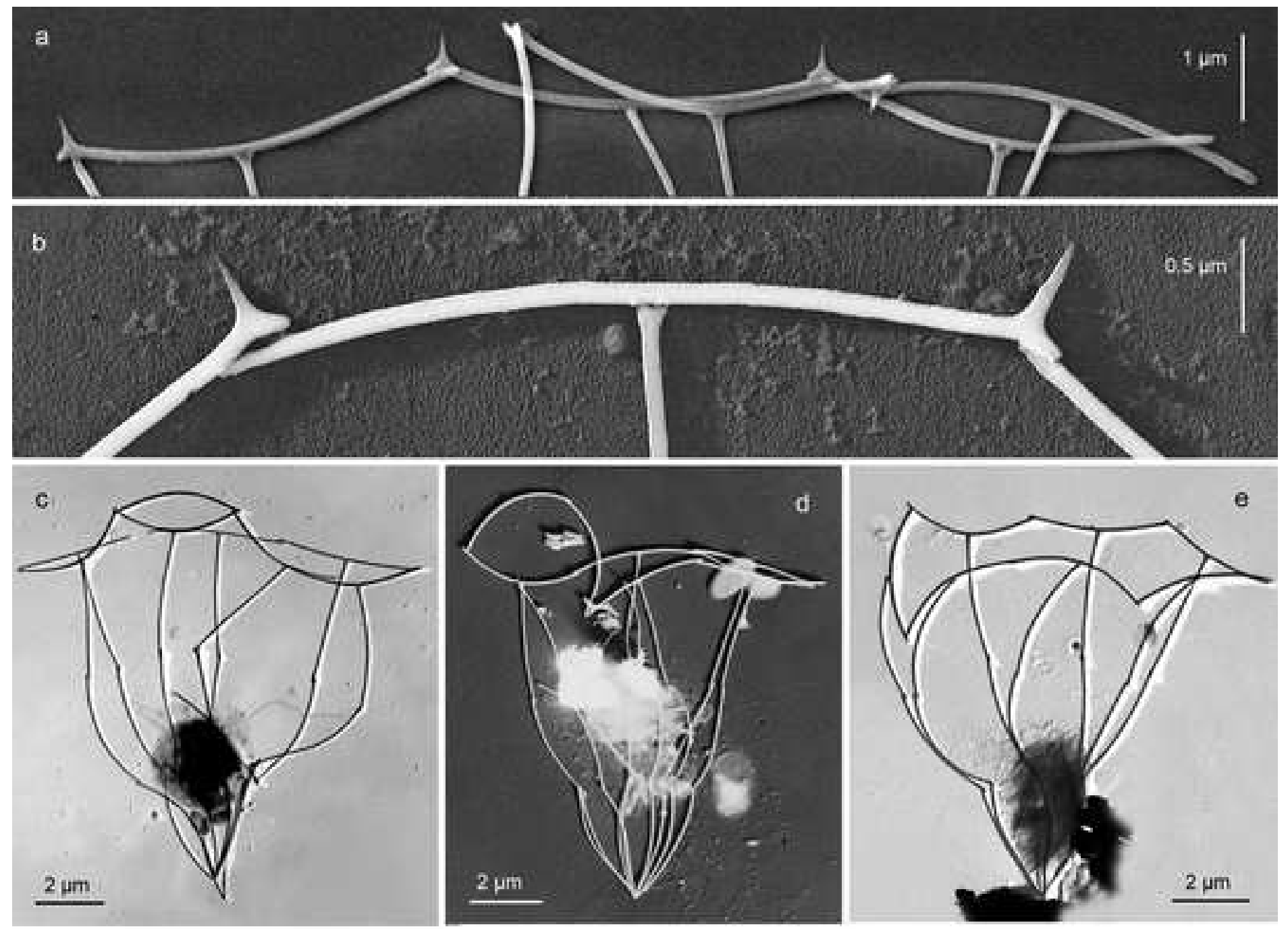


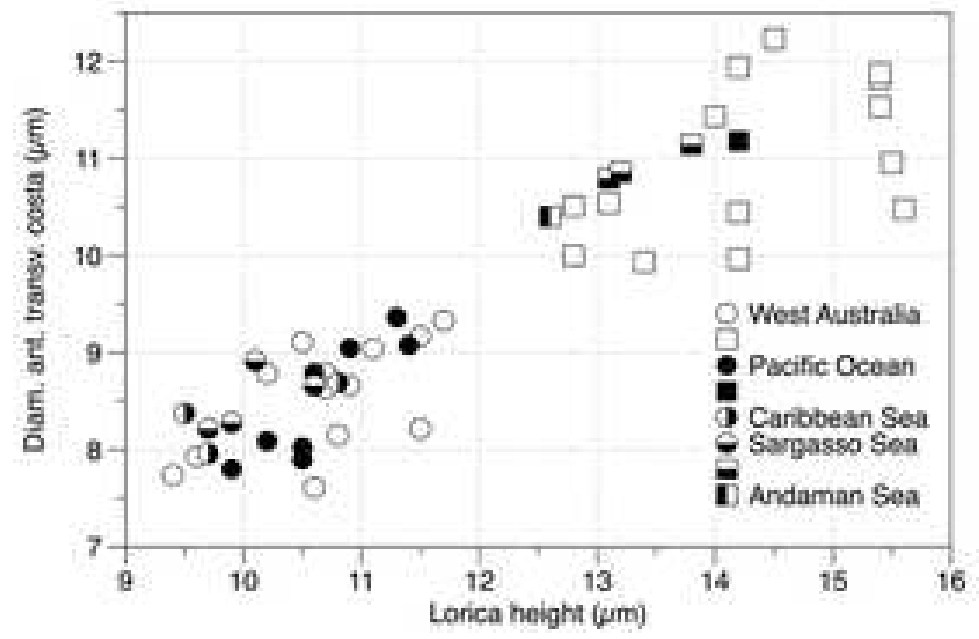



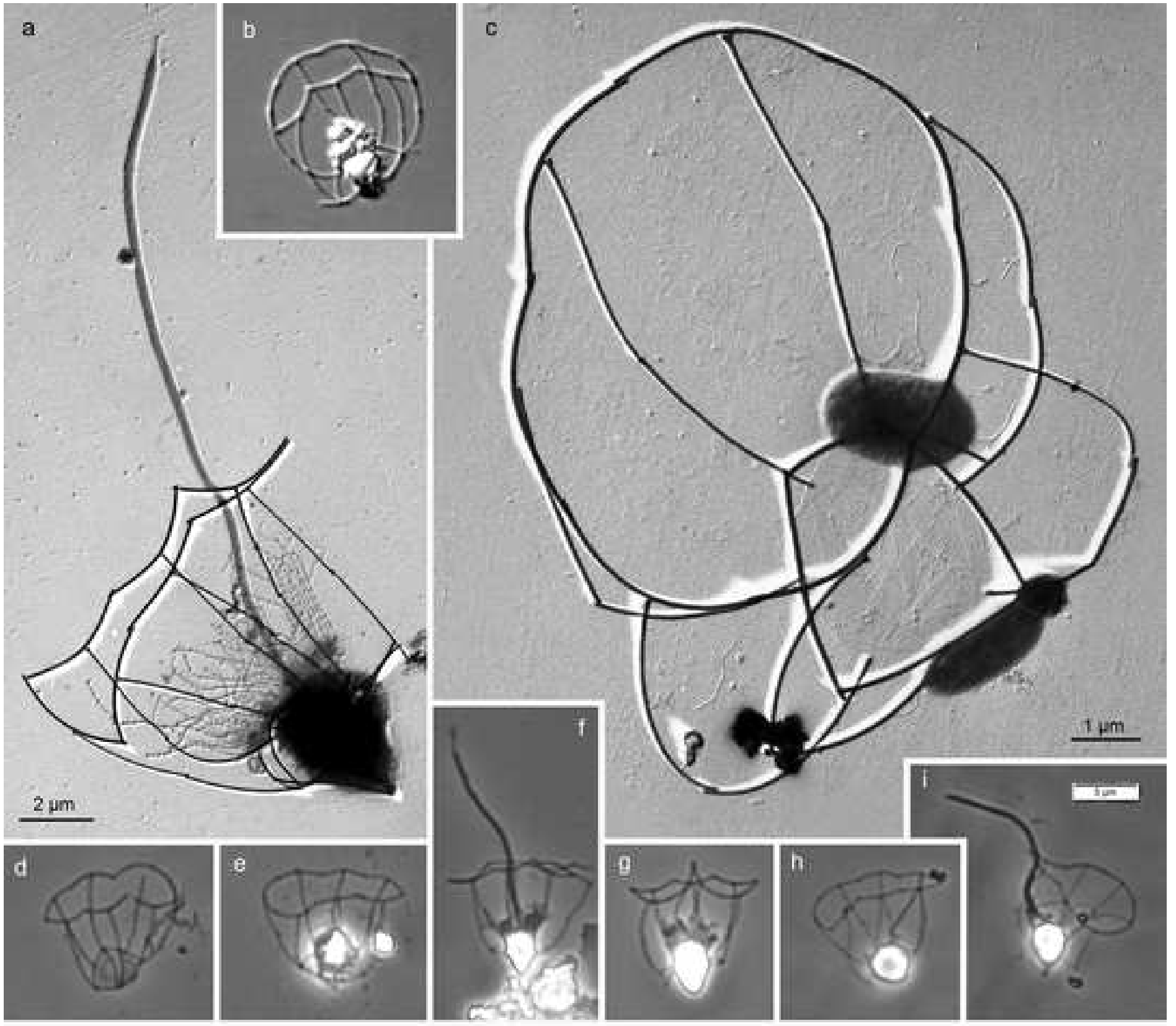


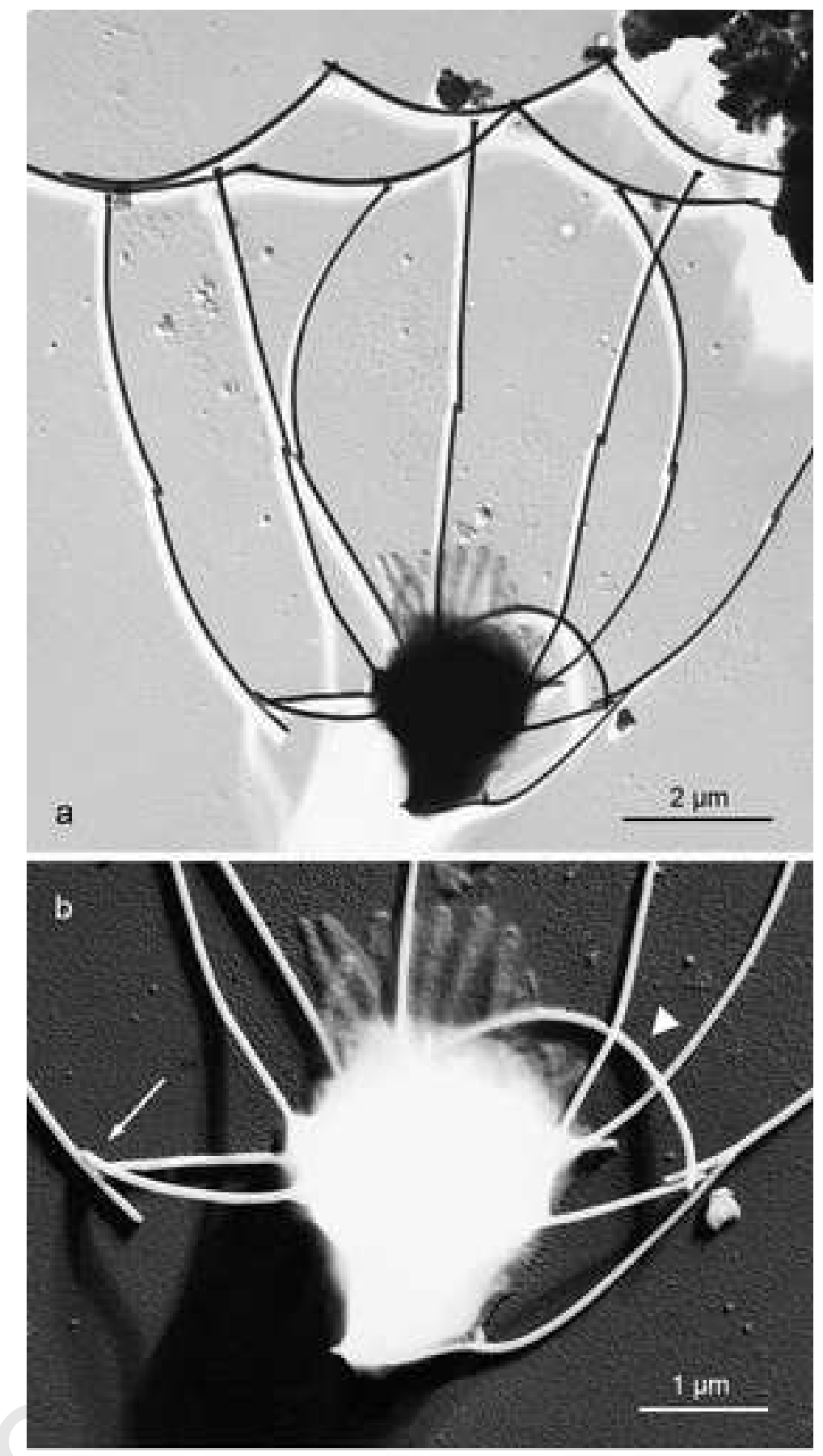



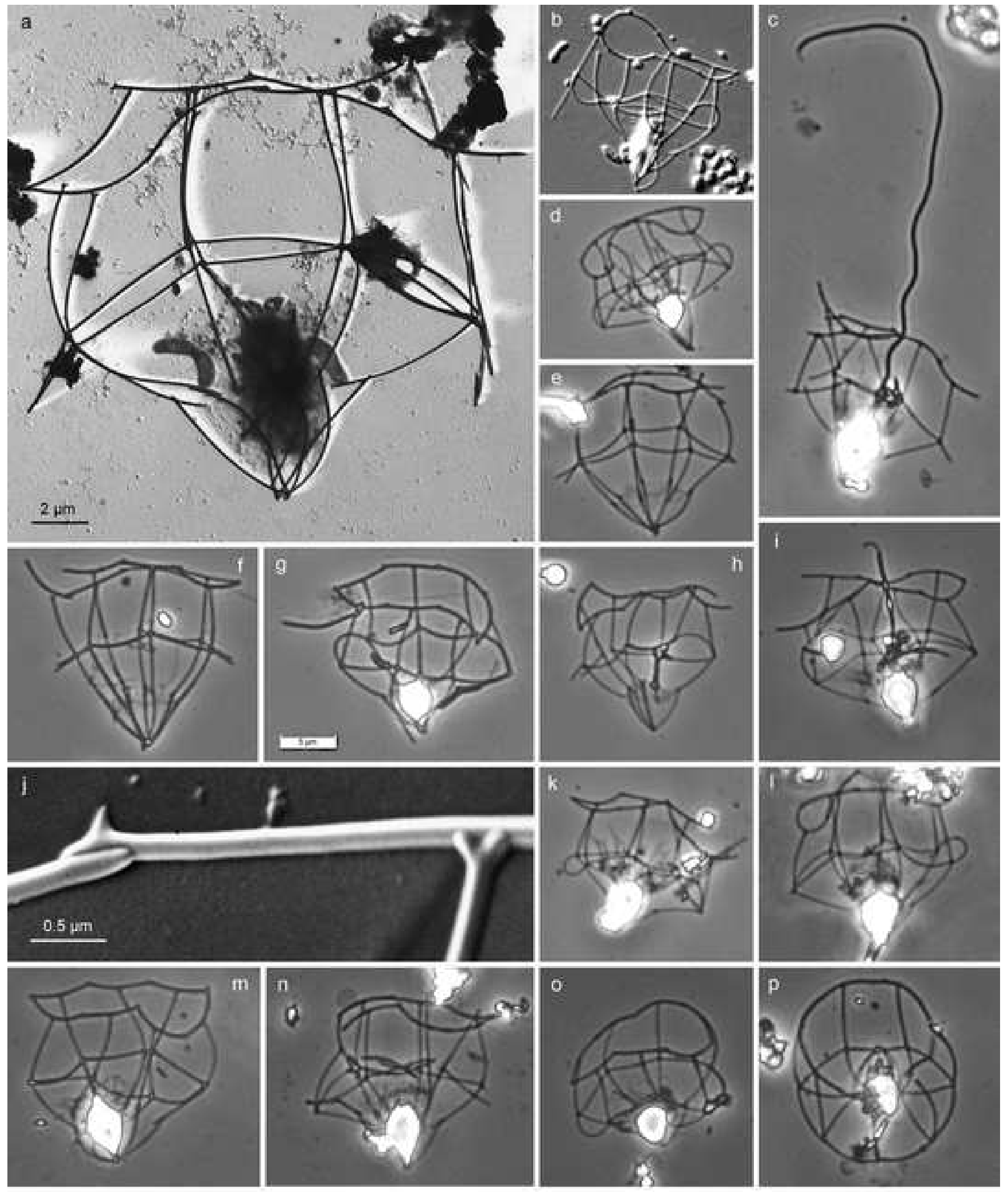

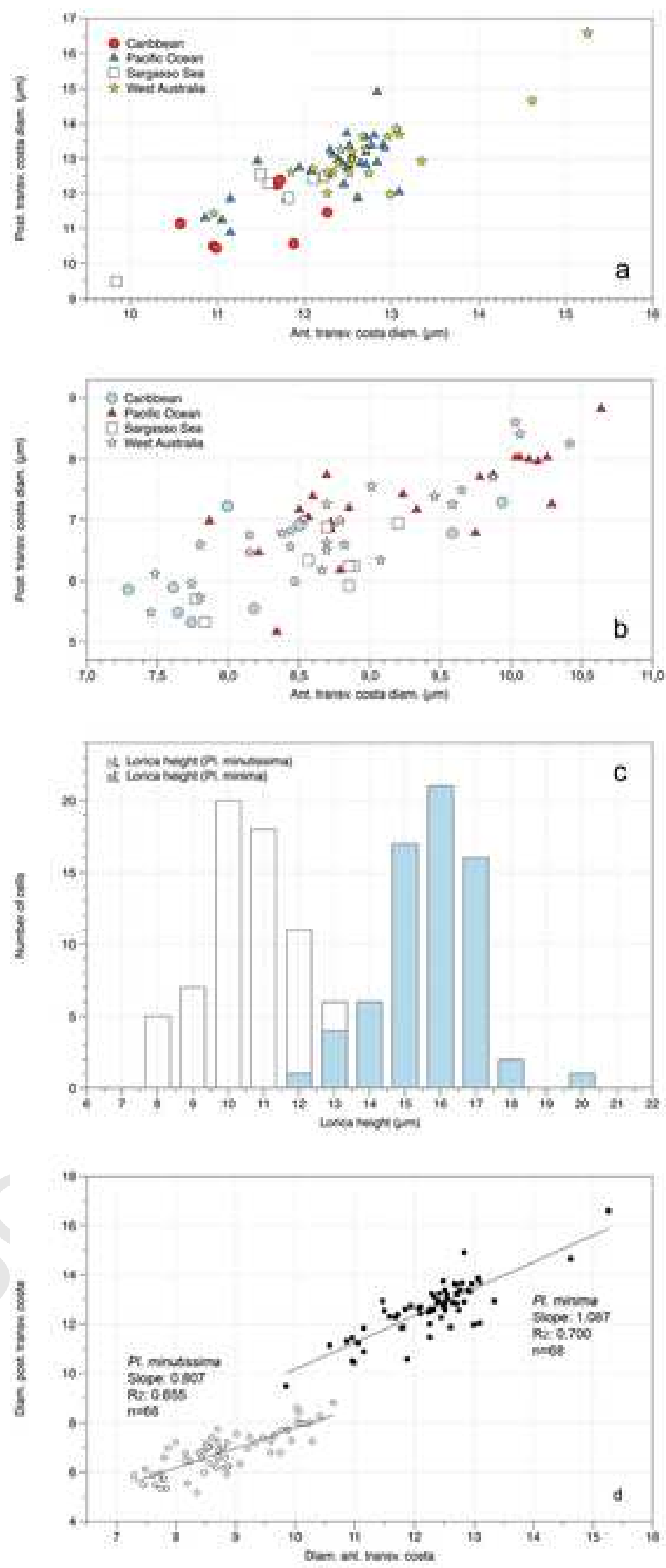


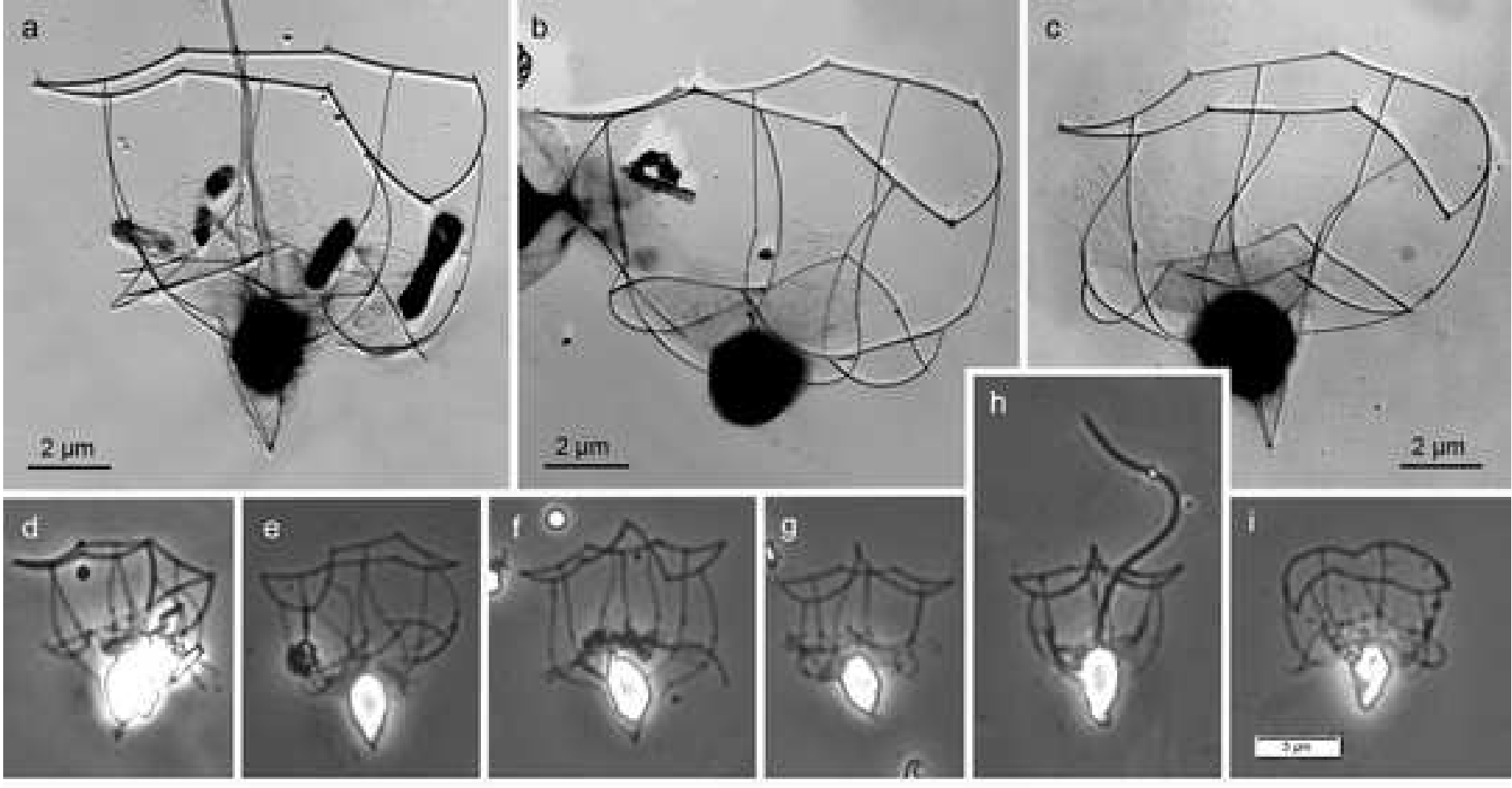


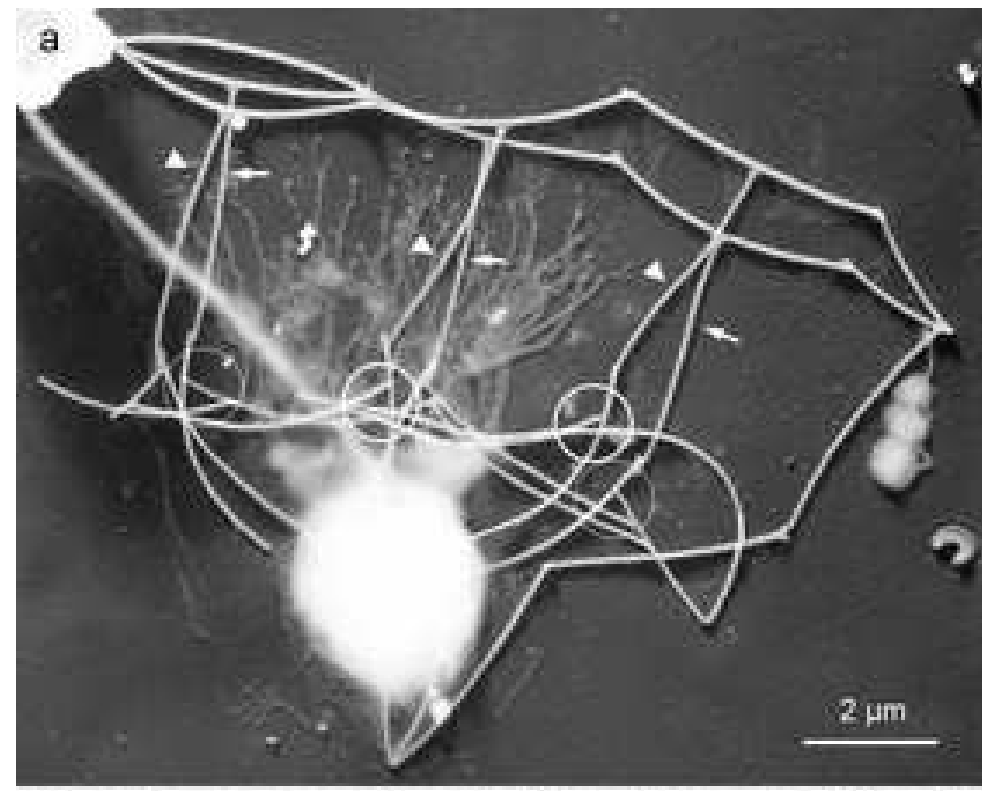

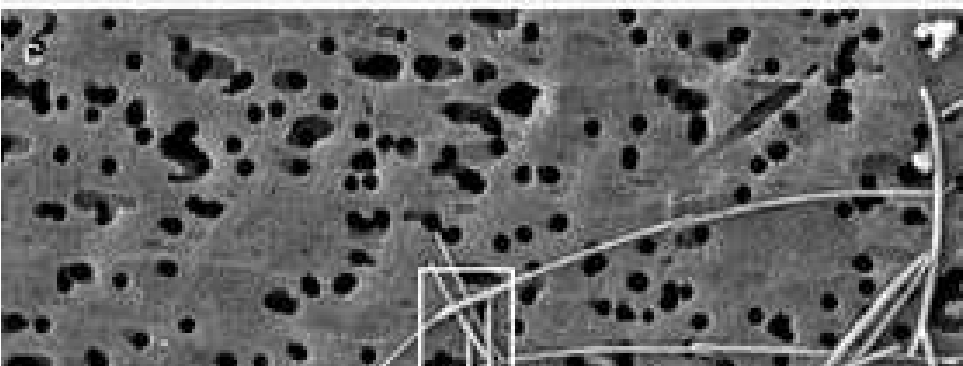

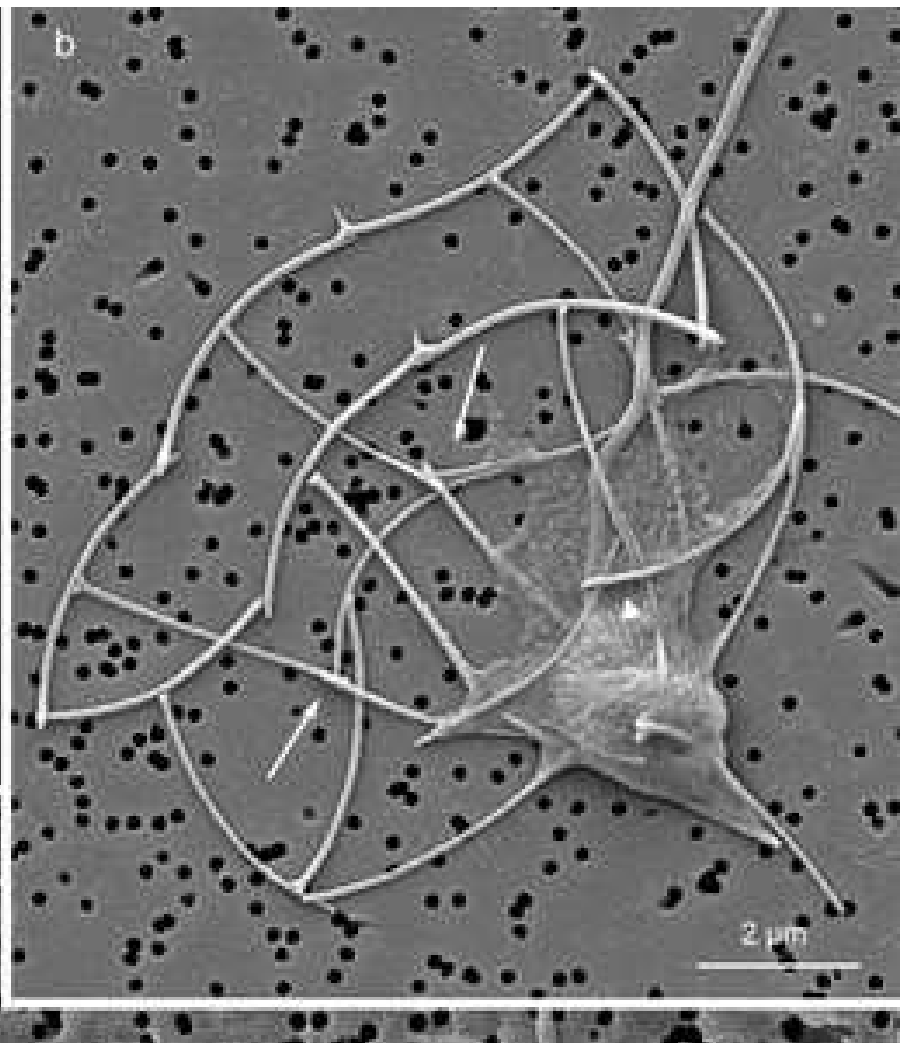

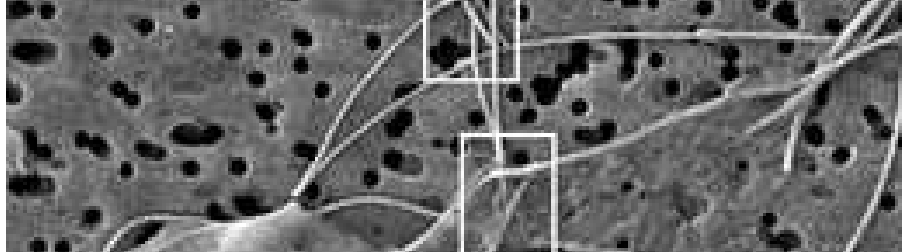

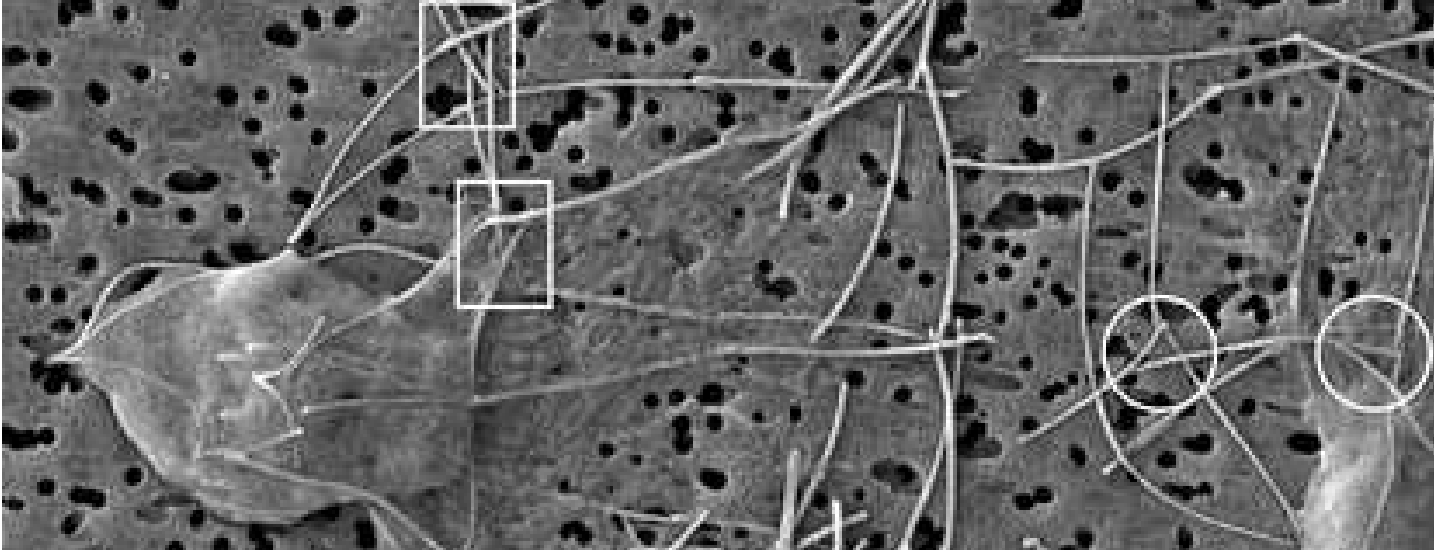

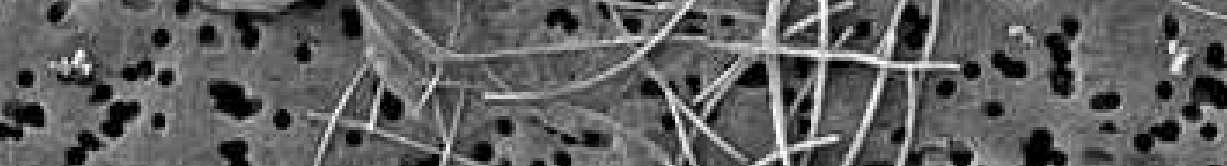

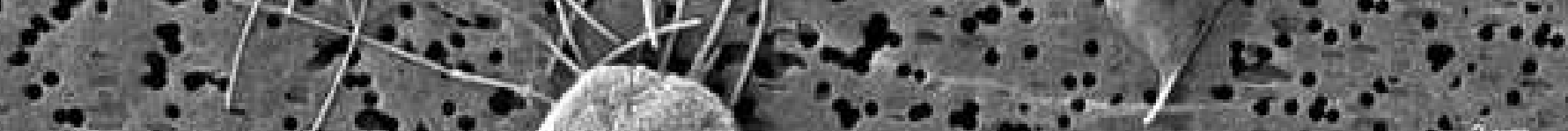

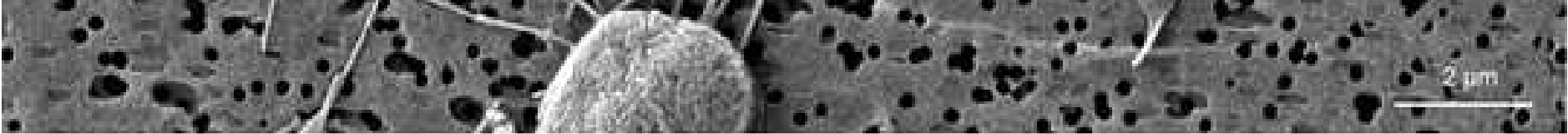





\section{Credit author statement}

Helge Abildhauge Thomsen: Conceptualization, Methodology, Analysis, Investigation, Resources, Writing - Original Draft, Funding acquisition; Nina Kamennaya: Investigation, Methodology, Resources, Writing - Review \& Editing; Mikhail V. Zubkov: Resources, Funding acquisition; Jette Buch $\emptyset$ stergaard: Investigation, Resources. 